Technische

Universität

Berlin

Nina Langen, Pascal Ohlhausen, Fara Steinmeier, Silke Friedrich, Tobias Engelmann, Melanie Speck, Kerstin Damerau, Katrin Bienge, Holger Rohn, Petra Teitscheid

\title{
Nudges for more sustainable food choices in the out-of-home catering sector applied in real-world labs
}

Open Access via institutional repository of Technische Universität Berlin

\section{Document type}

Journal article | Accepted version

(i. e. final author-created version that incorporates referee comments and is the version accepted for publication; also known as: Author's Accepted Manuscript (AAM), Final Draft, Postprint)

This version is available at

https://doi.org/10.14279/depositonce-15150

\section{Citation details}

Langen, N.; Ohlhausen, P.; Steimeier, F.; Friedrich, S.; Engelmann, T.; Speck, M.; Damerau, K.; Bienge, K.; Rohn, H.; Teischeid, P. (2022): Nudges for more sustainable food choices in the out-of-home catering sector applied in real-world labs. Resources, Conservation and Recycling, 180, 106167.

https://doi.org/10.1016/j.resconrec.2022.106167. 
This is the Accepted Manuscript of: Langen, N., Ohlhausen, P., Steinmeier, F., Friedrich, S., Engelmann, T., Speck, M., ... Teitscheid, P. (2022). Nudges for more sustainable food choices in the out-of-home catering sector applied in real-world labs. Resources, Conservation and Recycling, 180, 106167. https://doi.org/10.1016/j.resconrec.2022.106167

(C) 2022. This manuscript version is made available under the CC-BY-NC-ND 4.0 license https://creativecommons.org/licenses/by-nc-nd/4.0/

\title{
Nudges for more sustainable food choices in the out-of-home catering sector applied in real-world labs
}

\author{
Nina Langen ${ }^{1, *}$, Pascal Ohlhausen ${ }^{1}$, Fara Steinmeier ${ }^{2}$, Silke Friedrich ${ }^{2}$, Tobias Engelmann ${ }^{2}$, Melanie \\ Speck $^{3,4}$, Kerstin Damerau ${ }^{1}$, Katrin Bienge ${ }^{4}$, Holger Rohn $^{5}$ and Petra Teitscheid ${ }^{2}$ \\ 1 Institute of Vocational Education and Work Studies, Department Education for Sustainable Nutrition and Food \\ Science, Technische Universität Berlin, 10587 Berlin, Germany \\ 2 Institute of Sustainable Nutrition, University of Applied Sciences Münster, 48149 Münster, Germany \\ ${ }^{3}$ Hochschule Osnabrück, University of Applied Sciences, Albrechtstr. 30, 49076 Osnabrück \\ 4 Wuppertal Institute for Climate, Environment and Energy, 42103 Wuppertal, Germany \\ 5 Department of Industrial Engineering, University of Applied Sciences Mittelhessen, 61169 Friedberg, Germany \\ * Correspondence: nina.langen@tu-berlin.de
}

\begin{abstract}
Food production is responsible for approximately 17\% of Germany's greenhouse gas (GHG) emissions. After retail, out-of-home catering is the second largest food sales channel in Germany. A variety of means on both the supply and demand side are necessary to stimulate, facilitate and encourage a more sustainable development and minimise GHG emissions in this sector. Nudges are one of these. This paper's focus lies on the demand side. Set in real-world laboratories, we use a standardised empirical approach to compare different nudging interventions belonging to the area of physical environment and consumers' choice making process. We compare the effects of the same intervention across different settings and the effect of different, sequential nudging interventions in the same setting. Data was collected in eight workplace and school cafeterias in Germany over two project iterations (2016/2017; 2019/2020). A similar intervention design was applied. Comparability was assured by a harmonised menu. The first project iteration revealed that only one nudge (top menu position, $+22.5 \%$ ) led to significant increases in sustainable food choices, while results from the second iteration showed that all nudge interventions (best counter position, $+11.6 \%$; top menu position, $+6,9 \%$; label plus information, $+15.9 \%$ ) positively influenced consumer choice. Possible explanations such as the stricter compliance to the experimental design in the cafeterias but also societal developments such as the appearance of the Fridays for Future movement are discussed. As results vary between specific locations and settings, our findings suggest that nudges need to be adjusted to situational conditions for achieving highest efficacy.
\end{abstract}

Keywords: out-of-home; food choices; nudge; cafeteria; intervention; sustainable nutrition.

\section{Introduction}

Current worldwide food production, processing and distribution is estimated to be responsible for at least $21 \%$ of global anthropogenic greenhouse gas (GHG) emissions; with a range up to $42 \%$ of GHG emissions (Crippa et al., 2021; Mbow et al., 2019; Poore and Nemecek, 2018). Their reduction is a necessary step for a sustainable transformation of the global food systems; one of the biggest prerequisites to achieving the Sustainable Development Goals by 2030, twelve of which are highly relevant for achieving nutrition security (Black, 2013; Rockström and Sukhdev, 2016). In countries like Germany, where the national food supply was responsible for $20 \%$ of GHG emissions in 2015 (Crippa et al., 2021), out-of-home catering plays an increasingly important role in the daily nutrition of the population. Due to the sector's steady growth rates over the last 
decades, awareness for environmental issues is also rising (Kasim and Ismail, 2012; Peinelt and Wetterau, 2015; Reisch et al., 2013; Rückert-John, 2005; Teitscheid, 2011; Wahlen et al., 2012). Awareness by itself does not suffice to change structures, procedures and behaviors. Thus, to support decision-makers and effectively reduce the negative impact of the out-of-home catering sector, we need to develop specific approaches and change measures. To arrive at manageable measures to reduce negative sustainability impact of the out-of home catering sector, one can break the comprehensive issue down to the level of the kitchens' product: the meal. At the level of the dishes prepared and consumed four different dimensions of sustainability (economy, society, environment and health) need to be addressed (Burlingame and Dernini, 2012). In this regard, relevant impact factors on the supply side at the level of the ingredients are the efficiency of supply chains (Göbel et al., 2015; Wang et al., 2013), product quality (e.g. conventional, organic or local food) (Risku-Norja et al., 2009) and recipe composition (Speck et al., 2020). On the demand side, recent research revealed that choice architecture (e.g. the shape of a plate) (Richardson et al., 2020) and associated consumers perception as well as consumer habits (e.g. consumption of animal-source foods or creation of leftovers) (Ivanova et al., 2020; Lorenz et al., 2017; Lorenz-Walther and Langen, 2020; Ohlhausen and Langen, 2021) determine sustainability. Like in every market, the final interplay between supply and demand side determines overall sustainability performance of the sector.

On the supply side, ingredients and processing can be improved via rational optimisation considerations by staff that is specifically trained in regard to sustainability assessment tools. Engelmann et al. (2018) and Speck et al. (2020) developed such a tool, which provides sustainability indicators of ingredients and preparation methods for each sustainability dimension that can guide staffs' improvement activities. The tool's output can also be used to guide consumer behaviour via various nudging approaches. Demand side changes need to acknowledge that food choices are not always a result of extensive decision making but influenced by several determinants (see Lorenz and Langen, 2017 for a review). Furthermore, food is generally regarded as a low involvement good with limited cognitive effort given to decision making (Bell and Marshall, 2003; Russo et al., 1986). However, the more consumers attach certain values to sustainability and ethical food product characteristics, the more food choices become relevant, increasing at least short-term involvement. This is a chance to increase sustainable food consumption. Research on the demand side focusses primarily on either behaviour- or information-based strategies to guide and support consumer decision making towards more sustainable food choices (Lorenz-Walther and Langen, 2020; Ohlhausen et al., 2018; Saulais, 2015). Implementing nudges targeting either system 1 (fast and automatically effortless thinking and behaviour, using heuristics; called system 1 nudges) or system 2 (reflective, slow and effortful thinking and information 
processing; called system 2 nudges) can be used to alter food choices towards more sustainable options without significantly changing economic incentives or forbidding any options (Filimonau et al., 2017; Melissen, 2013; Myung et al., 2012; Visschers et al., 2020).

Based on the findings of Lorenz and Langen (2017) concerning the various options to alter consumer food choices towards more sustainability, this study examines the efficacy of different type 1 and type 2 nudges focussing on the step of food choice and at the level of the physical environment. Even though the effectiveness of nudges is context-specific - as decision making is context-dependent according to Thaler and Sunstein - a systematic comparison of the same interventions in different settings has yet to been done. The out-of home catering is the second biggest food distribution channel (BVE, 2020,2019) and is comprised of community food services, including school catering, restaurants, company catering and takeaway (for an overview see Göbel et al. (2017)) with varying structures and target groups. Recommendations for the entire out-of home catering sector cannot be referred by single case studies with limited reliability (see also Lin et al. 2017). To increase external reliability of experiments examining nudges, there is a need for standardising methods examining nudges and to investigate and detect patterns of evidence across different settings (Lin et al. 2017). Thus, to enable informed decision making within the sector, a comparison of the same nudging intervention across settings controlling e.g. for the length of the interventions applied is needed.

On these grounds, we compare the effects of (1) the same nudge intervention across different settings and (2) the effect of different, sequential nudging interventions in the same setting in harmonised real world labs and contribute to literature in this way. Goal is to support the transformation of the food system by giving insights into the most promising nudges for the out-of-home catering and thereby increase sustainable food choices in this sector. Based on a harmonised menu offered over equal time spans, we tested both nudging approaches in eight cafeterias in real world lab settings: two hospital staff, three company, and three school or university cafeterias. These locations served as out-of-home real-world laboratories, where scientists and the public cooperate in a pre-determined and specifically prepared space to produce new insights and knowledge in order to support a more sustainable development of society (Groß et al., 2005). Three or more consecutive interventions were conducted in each cafeteria within the NAHGAST ${ }^{1}$ project phase I and phase II (see Table 4), tracking resulting changes in meal sales.

\footnotetext{
${ }^{1}$ NAHGAST is a project that focuses on the development, provision and dissemination of concepts for sustainable production and consumption in the out-of-home catering sector. Its overall goal is to stimulate, facilitate and encourage a sustainability transformation, taking both sustainable food production as well as consumer food choices into account. It was funded as NAHGAST I from 2015-2018 and as NAHGAST II from 2019-2021. For further information, see www.nahgast.de
} 


\section{Background - Where to intervene out-of-home given the diverse factors influencing decision making}

Applying Bronfenbrenner's (1992) ecological systems theory idea that individual behaviour is influenced by different behavioural systems, Lorenz and Langen (2017) provide a structured review of the existing research body on the determinants of individual food choices and out-of-home food consumption. There are four behavioural systems relevant for out-of-home catering: Microsystems composed of direct personal relationships and mutual influences between the individual and familiar others including personal knowledge, food literacy, nutritional involvement and attitudes. Mesosystems describing interactions of different settings or groupings of microsystems such as the social environment including family, friends and colleagues, social norms influencing personal behaviour (e.g. whether other guests care to finish their plate constitutes a social norm). Exosystems comprised of environmental influences over which a person does have no or very little control such as the physical surroundings as well as access and availability of particular dishes. And lastly, macrosystems composed of patterns impacting micro-, meso- and exosystems (Story et al., 2008). Macrosystems include food and health policies such as national school lunch programs and dietary recommendations. These indirectly affect what people choose to eat.

Combining this categorisation with Sobal \& Bisogni's (2009) food choice process models steps of choosing a dish, serving, eating, cleaning up and paying for it at any time within or at the end of these steps, we derive a combined modelling framework (Appendix Figure A1). The framework illustrates possible entry points (e.g. serving counter, table) to alter and to assess consumer behaviour. This allows us to identify possible turning points of consumer choice behaviour. At this point, an implementation of system 1 and 2 nudges appears most promising. At every step within the process from choosing to cleaning up, choice architects can create physical environments to facilitate sustainable food choices. Further, the social environment as well as individual characteristics can influence food choice and eating behaviour as well as leftovers during the process. As a result, a variety of different interventions can be designed for each combination of steps in the food choice process and behavioural systems. For example, information can be provided at the tables where guests are eating in order to raise awareness for particular sustainability issues, e.g. biodiversity aspects of served foods. As dish selection is the first relevant step toward creating sustainable out-of-home food consumption, our interventions focus on this particular step (dish positioning at the counter, on the menu and adding labels to the dishes at the counter) ${ }^{2}$. If the sustainable option has been chosen, other steps can be carefully examined further.

\footnotetext{
${ }^{2}$ During the NAHGAST project, interventions for the steps 'serve' and 'eat' were also carried out. With the use of different posters (prompts, social norms, prompts \& social norms, setting-specific) cafeteria guests were nudged to reduce
} 
In conclusion, interventions might affect individual, social and physical environments and hence influence behaviour at several steps of the decision-making process. Having a closer look at the different types of interventions, dual processing theory can be used to distinguish two types of interventions. Dual processing theory distinguishes two approaches to general decision making; one supposes little involvement, while the other requires more involvement such as processing information provided by campaigns or labels (Jung and Mellers, 2016; Thaler and Sunstein, 2008). This assumption is supported by a differentiation into two types of thinking, the fast, automatic and emotional system 1 thinking and the slow, logical and conscious system 2 thinking (Kahneman, 2011). Some nudges, first defined by (Thaler and Sunstein, 2008), are small changes in choice architecture, affecting individuals subconsciously through changes in the physical environment without impacting freedom of choice and work when system 1 thinking is prevalent. The ease of application depends on the situation and limited cognitive resources of consumers. Default options, such as reduced portion sizes, and status-quo options, such as the placement of the most sustainable dish at the most visible or mostly frequented counter, are more likely to not affect conscious thinking, require less involvement and belong to system 1 nudges (Jung and Mellers, 2016; Sunstein, 2016a). Humans selective nature of attention leads to the observation that changing serve or menu position (in our study used to increase respective sales of the most sustainable dish) can be considered a system 1 nudge because the ordering of dishes on a menu influences what guests choose (Dayan and Bar-Hillel, 2011).

Other nudges, system 2 nudges, are intended to strengthen system 2 thinking and require more cognitive involvement and hence conscious decision making. Informational labels on nutrition or sustainability make these product and process characteristics salient. They provide feedback on the sustainability-related impacts of eating choices. As such, they potentially augment decision makers' knowledge and address turning points, which influence individual behaviour primarily via conscious cognitive processes.

Both nudging categories ensure freedom of choice (Sunstein, 2016b) while being transparent and easy and also cheap to avoid at any time (Thaler, 2015; Thaler and Sunstein, 2008). Studies show that nudges can be applied effectively in both the retail and the out-of-home catering sector (Arno and Thomas, 2016; Bauer et al., 2021; Broers et al., 2017; Harbers et al., 2020; Lehner et al., 2016; Skov et al., 2013; Vandenbroele et al., 2020; Velema et al., 2018; Wilson et al., 2016). To date, comparable standardised interventions with harmonised dishes in different cafeteria settings are rare. They are, however, needed in order to expand results from case studies, provide insights into the limitations and opportunities of different nudging techniques and to provide

their plate waste. Since the focus and the study design was different just as the practitioners, these interventions are not included in this paper. 
recommendations to practitioners either not motivated or capable of testing different options on their own. By standardising dishes offered in the settings during the baseline measurements and intervention weeks, we attain a data pool as harmonised as possible to (1) investigate whether there are consistent patterns of evidence across different settings and to (2) compare different nudge performances in the very same setting to identify the most promising ones.

The interventions described in this paper are the system 1 nudges improved visibility and accessibility of the most sustainable meals (i) at the counter and (ii) on the menu (both found to be effective, Campbell-Arvai et al., 2014; Just \& Wansink, 2009; Levy et al., 2012; Rozin et al., 2011). The system 2 nudges used were (iii) improved dish formulas including changing names of offered dishes (also discussed as suitable, Morizet et al., 2012), and labelling (Filimonau et al., 2017; Levy et al., 2012; Miller and Cassady, 2015). With respect to labeling, we tested two approaches: (iv) labelling the most sustainable dish without giving an explanation of the label and (v) labelling plus explanation. Interventions are evaluated using sales data representing revealed behaviors.

\section{Hypotheses}

Our work contributes to the existing literature by providing a systematic comparison of the effectiveness of nudges that until now have only been tested in separate case studies. We therefore build upon the previous literature and test previously established effects in different practical field settings under harmonised conditions. Previous literature demonstrates that changing serving or counter position of a dish can lead to significant impacts on sales (Bucher et al., 2016; Hanks et al., 2012; Just and Wansink, 2009; Levy et al., 2012; Rozin et al., 2011). These nudges both address the physical environment in which guests make their food choice. Our real-world lab practice partners' aim was to test promising approaches. Hence, we tested the extent to which moving the dish with the highest sustainability rating to the best counter position influences customer choice (see Appendix Figure A2). We determined the best counter position based on sales data from the baseline measurements as well as sales experience of participating cafeterias. With the same menu position throughout baseline and interventions, we hypothesised based on the previously established effects: (i) "The sales of the most sustainable dishes of the day can be increased significantly by moving them to the best counter position". Besides counter position, also menu position of the respective dishes can be changed (Campbell-Arvai et al., 2014; Filimonau et al., 2017; Lehner et al., 2016), impacting sales especially at the top or end of the menu (Dayan and Bar-Hillel, 2011). With the aim of positioning dishes with the highest sustainability rating of the day at the top of the menu (see Appendix Figure A3), yet keeping counter positions equal, we hypothesised 
based on the previously established effects: (ii) "The sales of the most sustainable dishes of the day can be increased significantly by moving them to the best menu position”.

Descriptive (food) names were shown to be effective out-of-home (Morizet et al., 2012; Ohlhausen and Langen, 2020). Keeping counter and menu positions equal throughout baseline and interventions, we hypothesised based on the previously established effects: (iii) "The sales of the most sustainable dishes of the day can be increased significantly by using improved formulas indicated by descriptive names". Recipes of the most sustainable dishes have been improved by applying the NAHGAST calculator and the dish-specific outstanding sustainability aspects of improvement were highlighted with descriptive names. In the following intervention periods, these improved recipes remained unchanged. One can argue that the name of the dish could be considered a non-informational nudge that is not comparable to an explicit label such as a traffic light or a fair trade label. On the other side, as the name of the dish is consciously used to influence a choice, it can be considered a system 2 nudge. With regard to system 2 nudges, studies have investigated the effects of nutrition information and food labels on consumer choice (Grunert and Wills, 2007; Janßen and Langen, 2017; Miller and Cassady, 2015), displaying information not only numerically but also via distinctive colouring or labels (Filimonau et al., 2017; Levy et al., 2012). We tested whether consumer choices can be influenced purely by the presence of a label being presented at an A4 sized advertising stand at the food counter (see Appendix Figure A4, A5). Keeping counter and menu positions equal throughout baseline and interventions, we hypothesised based on the previously established effects: (iv) "The sales of the most sustainable dishes of the day can be increased significantly by the display of sustainability labels without any explanation". The approach to display a label without any information was inspired by the current situation in supermarkets. There, diverse labels are displayed but seldomly explained. In addition, in the following intervention, we tested whether providing information shortly explaining the label at the point of choice might influence sales. Based on the previously established effects hypothesis (v) is "The sales of the most sustainable dishes of the day can be increased significantly by the display of sustainability labels in combination with an explanation".

When implementing nudges, studies supposed that not only specific nudge interventions themselves, but also the choice environment (Dhar and Novemsky, 2008; Winkler et al., 2018) and therefore particular choice settings, situations and meals offered play an important role for decision making. As food choices as well as meal preparations between settings could have deviated due to different guest characteristics such as age, gender and education level we did not control for, we hypothesised based on the previously established effects: (vi) "The results of our nudge interventions are not consistent between intervention partners", as well as (vii): "The results of our nudge interventions are not consistent between the most sustainable dishes on offer". 


\section{Methods}

\subsection{Intervention design}

To standardise the method for examining different nudging interventions, a specific data collection scheme

(Table 1) has been developed. Firstly, all partners agreed on a harmonised menu developed in collaboration with kitchen chefs to be offered during all measurement weeks. Secondly, sales of the respective dishes of this harmonised menu week were recorded in baseline measurement weeks and used as reference data. Thirdly, after baseline measurements several intervention weeks followed each other starting with type 1 nudges and closing with the type 2 nudge providing the most comprehensive level of information tested in the project. Each nudge was applied for a whole week and accompanied the dish with the highest daily sustainability rating. The harmonised menu was offered every four to six weeks. As a result, the same dishes of the so called 'intervention week' were offered repeatedly across all cafeterias, yet always with a different nudge resulting in a series of consecutive nudges that could be compared to our baseline week.

Table 1. Data collection scheme applied synchronised in participating cafeterias.

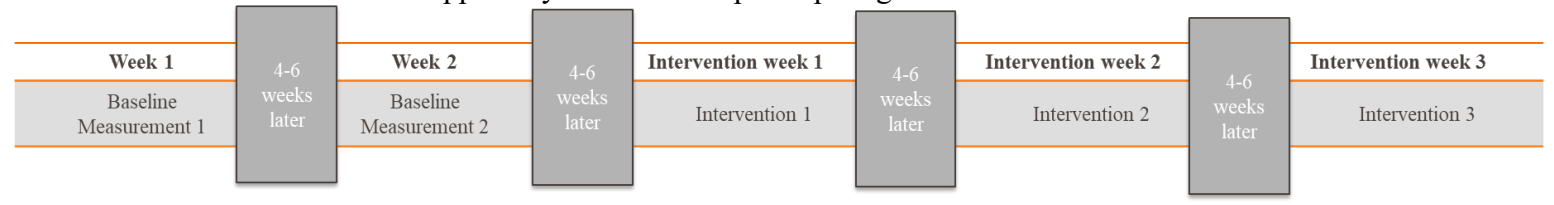

Regarding the harmonised menu, final preparations did somewhat vary between cafeterias, while main ingredients for each meal were agreed upon in advance, making dishes comparable across locations and between baseline measurements and intervention weeks. However, there were some differences between project iterations NAHGAST I and II due to the change of participating cafeterias. The menu was comprised of 15 dishes typical for the German out-of-home catering sector, with three meals being offered daily, at least one of which being a vegetarian or entirely plant-based option. These meals are referred to as NAHGAST dishes throughout this paper as their sustainability performance was calculated and they were used to assess the effectiveness of the different nudges. Meal prices did not deviate between baseline and intervention weeks.

Table 2. Overview of the harmonised menu of NAHGAST II, so called NAHGAST dishes and sustainability ratings based on the results of the dish sustainability calculation tool $(1=$ low to $6=$ high $)$.

\begin{tabular}{|c|c|c|c|c|c|c|c|c|c|}
\hline 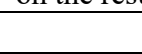 & \multicolumn{3}{|c|}{ Dish 1} & \multicolumn{3}{|c|}{ Dish 2} & \multicolumn{3}{|c|}{ Dish 3} \\
\hline & 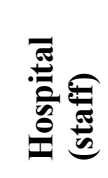 & 离 & 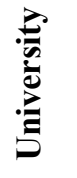 & 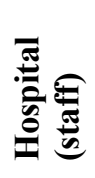 & 离 & 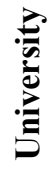 & 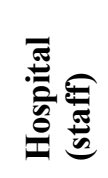 & $\stackrel{\grave{E}}{\grave{E}}$ & 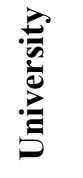 \\
\hline Monday & \multicolumn{3}{|c|}{ Beef goulash and spaetzle } & \multicolumn{3}{|c|}{$\begin{array}{c}\text { Bratwurst and mashed } \\
\text { potatoes }\end{array}$} & \multicolumn{3}{|c|}{$\begin{array}{c}\text { Entirely plant-based } \\
\text { Chickpea curry with rice }\end{array}$} \\
\hline
\end{tabular}




\begin{tabular}{|c|c|c|c|c|c|c|c|c|c|}
\hline Environment (33\%) & 2 & 2 & 2 & 4 & 4 & 3 & 5 & 4 & 4 \\
\hline Health $(50 \%)$ & 4 & 4 & 3 & 4 & 4 & 3 & 5 & 6 & 6 \\
\hline Fairness $(17 \%)$ & 4 & 1 & 4 & 4 & 1 & 1 & 5 & 4 & 4 \\
\hline Dish Rating & 3.33 & 2.83 & 2.83 & 4.00 & 3.50 & 2.67 & 5.00 & 5.00 & 5.00 \\
\hline Tuesday & \multicolumn{3}{|c|}{ Lentil stew and sausages } & \multicolumn{3}{|c|}{$\begin{array}{l}\text { Meatball with kohlrabi and } \\
\text { potatoes }\end{array}$} & \multicolumn{3}{|c|}{$\begin{array}{c}\text { Rice bowl with } \\
\text { vegetables }\end{array}$} \\
\hline Environment (33\%) & 5 & 4 & 4 & 4 & 3 & 3 & 5 & 4 & 4 \\
\hline Health $(50 \%)$ & 4 & 5 & 4 & 4 & 4 & 4 & 4 & 6 & 5 \\
\hline Fairness $(17 \%)$ & 1 & 1 & 1 & 4 & 1 & 1 & 4 & 4 & 4 \\
\hline Dish Rating & 3.83 & 4.00 & 3.50 & 4.00 & 3.17 & 3.17 & 4.33 & 5.00 & 4.50 \\
\hline Wednesday & \multicolumn{3}{|c|}{$\begin{array}{l}\text { Schnitzel with fried } \\
\text { potatoes / fries }\end{array}$} & \multicolumn{3}{|c|}{ Spinach salmon lasagna } & \multicolumn{3}{|c|}{$\begin{array}{c}\text { Potato bowl with } \\
\text { vegetables }\end{array}$} \\
\hline Environment (33\%) & 3 & 2 & 2 & 5 & 4 & 4 & 5 & 4 & 4 \\
\hline Health $(50 \%)$ & 3 & 4 & 4 & 5 & 4 & 4 & 5 & 4 & 5 \\
\hline Fairness $(17 \%)$ & 6 & 1 & 1 & 1 & 1 & 4 & 4 & 1 & 4 \\
\hline Dish Rating & 3.50 & 2.83 & 2.83 & 4.33 & 3.50 & 4.00 & 4.83 & 3.50 & 4.50 \\
\hline Thursday & \multicolumn{3}{|c|}{$\begin{array}{l}\text { Chicken steak with } \\
\text { potatoes }\end{array}$} & \multicolumn{3}{|c|}{$\begin{array}{c}\text { Vegetarian spaghetti } \\
\text { Bolognese }\end{array}$} & \multicolumn{3}{|c|}{$\begin{array}{l}\text { Falafel with bulgur / } \\
\text { couscous and vegetables }\end{array}$} \\
\hline Environment (33\%) & 4 & 4 & 4 & 6 & 4 & 5 & 5 & 4 & 4 \\
\hline Health $(50 \%)$ & 5 & 5 & 4 & 5 & 6 & 4 & 5 & 4 & 3 \\
\hline Fairness $(17 \%)$ & 1 & 1 & 2 & 4 & 1 & 6 & 1 & 4 & 4 \\
\hline Dish Rating & 4.00 & 4.00 & 3.67 & 5.17 & 4.50 & 4.67 & 4.33 & 4.00 & 3.50 \\
\hline Friday & \multicolumn{3}{|c|}{ Pollock with potatoes } & \multicolumn{3}{|c|}{$\begin{array}{l}\text { Chicken fricassee with } \\
\text { rice and vegetables }\end{array}$} & \multicolumn{3}{|c|}{$\begin{array}{l}\text { Rice pudding with fruit } \\
\text { compote }\end{array}$} \\
\hline Environment (33\%) & 4 & 4 & 4 & 4 & 4 & 4 & 5 & 4 & 4 \\
\hline Health $(50 \%)$ & 4 & 4 & 3 & 5 & 4 & 4 & 4 & 3 & 4 \\
\hline Fairness $(17 \%)$ & 4 & 1 & 4 & 1 & 1 & 1 & 1 & 1 & 1 \\
\hline Dish Rating & 4.00 & 3.50 & 3.50 & 4.00 & 3.50 & 3.50 & 3.83 & 3.00 & 3.50 \\
\hline
\end{tabular}

Note: The most sustainable dishes of the day are displayed in bold. Dimension scores were weighted according to the number of overall contained indicators: environmental impact - 4 out of 12 indicators (33\%); health - 6 out of 12 (50\%); fairness for humans and animals - 2 out of $12(17 \%)$.

We then used the NAHGAST sustainability calculation tool (Engelmann et al., 2018; Monetti et al., 2021;

NAHGAST, 2020; Speck et al., 2020) to evaluate the sustainability of all dishes with respect to environmental, health and fairness indicators for humans and animals. Included environmental indicators are material consumption, GHG emissions, freshwater and land requirements. Selected nutritional and hence health indicators are energy content as well as dietary fibre, fat, carbohydrates, of which total sugar, and salt contents of entire dishes. Also animal welfare (e.g., sustainable fishing) and fair trade product standards for tropical imports were included regarding the social dimensions of food sustainability (Engelmann et al., 2018). Each dimension for each dish was rated by the dish sustainability calculation tool on a scale from 1 (low) to 6 (high), taking into consideration the location-specific modifications such as the use of organic ingredients. To be able to aggregate dimension-specific scores to one overall score for each dish, each dimension score was weighted according to the number of indicators it contains: Out of twelve indicators, four describe environmental impacts 
$(33 \%)$, health is described by six indicators $(50 \%)$, and the remaining two indicators $(17 \%)$ score fairness for humans and animals. To ensure that dishes with highest daily sustainability ratings were the same across locations, the most sustainable dishes of the day had to have the highest ratings across all cafeterias, irrespective of possible local ties of specific dish ratings. Table 2 gives an overview of the harmonised menu adopted for NAHGAST II and associated dish-specific sustainability ratings calculated by the NAHGAST calculator.

NAHGAST I interventions took place in five workplace and school cafeterias in the three regions Berlin, North Rhine-Westphalia and Hessen, Germany between autumn 2016 and autumn 2017. The settings included two company restaurants, one of which also open for the public, a hospital staff cafeteria, one university and one school cafeteria. Data for NAHGAST II was collected at three locations in the region North Rhine-Westphalia, Germany from autumn 2019 to spring 2020, one company, one hospital staff, and one university cafeteria (see Table 3). In contrast to NAHGAST I, only locations that offer exactly three main dishes a day were included in NAHGAST II. As NAHGAST I has revealed, such a limited menu was better suited to get comparable data between intervention weeks and cafeterias as a large number of additional alternative dishes could have confounded intervention results there (Ohlhausen et al., 2018).

Table 3. Overview of the characteristics of the cafeterias participating in NAHGAST I and II.

\begin{tabular}{|c|c|c|c|c|c|c|}
\hline & \multicolumn{3}{|c|}{ NAHGAST I } & \multicolumn{3}{|c|}{ NAHGAST II } \\
\hline Setting & Care & Business & Education & Care & Business & Education \\
\hline $\begin{array}{l}\text { Number of } \\
\text { cafeterias } \\
\text { participating }\end{array}$ & 1 & 2 & 2 & 1 & 1 & 1 \\
\hline Menu offered & $\begin{array}{l}\text { - Three } \\
\text { main } \\
\text { dishes } \\
\text { - Soups } \\
\text { - Salad } \\
\text { buffet }\end{array}$ & $\begin{array}{l}\text { - Several } \\
\text { main } \\
\text { dishes } \\
\text { - Soups } \\
\text { - Salad } \\
\text { buffet } \\
\text { - Desserts }\end{array}$ & $\begin{array}{l}\text { - Several } \\
\text { main } \\
\text { dishes } \\
\text { - Soups } \\
\text { - Salad } \\
\text { buffet }\end{array}$ & $\begin{array}{l}\text { - Three } \\
\text { main } \\
\text { dishes } \\
\text { - Pasta } \\
\text { buffet } \\
\text { - Salad } \\
\text { buffet } \\
\text { - Desserts } \\
\text { \& fruits }\end{array}$ & $\begin{array}{l}\text { - Three } \\
\text { main } \\
\text { dishes } \\
\text { - Starters \& } \\
\text { Soups } \\
\text { - Salad } \\
\text { buffet } \\
\text { - Desserts }\end{array}$ & $\begin{array}{l}\text { - Three } \\
\text { main } \\
\text { dishes } \\
\text { - Soups } \\
\text { - Salad } \\
\text { buffet } \\
\text { - Desserts }\end{array}$ \\
\hline $\begin{array}{l}\text { Dishes sold / } \\
\text { day }\end{array}$ & $\sim 270$ & $\sim 1,900$ & $\sim 3,470$ & $\sim 180$ & $\sim 140$ & $\sim 505$ \\
\hline
\end{tabular}

Table 4 provides an overview of all nudges tested in NAHGAST I and II. 
Table 4: Categories and list of interventions to nudge the most sustainable dishes of the day.

\begin{tabular}{|l|l|l|}
\hline \multicolumn{1}{|c|}{ Category } & \multicolumn{1}{|c|}{$\begin{array}{c}\text { NAHGAST I } \\
\text { (five cafeterias) }\end{array}$} & \multicolumn{1}{|c|}{$\begin{array}{c}\text { NAHGAST II } \\
\text { (three cafeterias) }\end{array}$} \\
\hline Baseline measurement & Baseline measurement & Baseline measurement 1 \\
\hline Baseline measurement & \multicolumn{1}{|c|}{-} & Baseline measurement 2 \\
\hline System 1 nudge & Counter position & Counter position \\
\hline System 1 nudge & Menu position & Menu position \\
\hline System 2 nudge & $\begin{array}{l}\text { Improved recipes \& } \\
\text { descriptive food names }\end{array}$ & $\begin{array}{l}\text { Label plus Information } \\
\text { (most sustainable dish) }\end{array}$ \\
\hline System 2 nudge & $\begin{array}{l}\text { Label only } \\
\text { (most sustainable dish) }\end{array}$ & $\begin{array}{l}\text { Label only } \\
\text { (all NAHGAST dishes) }\end{array}$ \\
\hline System 2 nudge & $\begin{array}{l}\text { Label \& Information } \\
\text { (all NAHGAST dishes) }\end{array}$ & - \\
\hline System 2 nudge &
\end{tabular}

The nudging interventions included changes in the choice architecture (system 1 nudges), e.g. improved visibility and accessibility of the most sustainable meals at the counter and on the menu (Campbell-Arvai et al., 2014; Just and Wansink, 2009; Levy et al., 2012; Rozin et al., 2011).

At least one intervention tested labelling formats (system 2 nudges), partially in combination with explanatory information in all settings. For this intervention type, we presented the results of the NAHGAST sustainability calculation tool on a pretested label (Langen et al., 2017), which combined all evaluated sustainability dimensions - environment, health and fairness - on a colour scale from red to green (see Appendix Figure A4, A5). During the information intervention weeks, this label was displayed in an A4 sized advertising stand at the food counter without any explanation ('label only' in Table 4) and with additional information (label plus information nudge). The 'label only' nudge was tested in two subsequent interventions in NAHGAST I. Firstly, the label was only displayed for the most sustainable of the three NAHGAST dishes offered (called Label only (most sustainable dish) in Table 4). In the following intervention, the label was presented on all three NAHGAST dishes and allowed a comparison across dishes (called Label only (all NAHGAST dishes) in Table 4). In the subsequent third intervention, the label was displayed on all three NAHGAST dishes and accompanied by an explanation.

Right after the system 1 nudge 'menu position' was tested, recipes for the most sustainable dishes of the day were improved using the NAHGAST sustainability calculation tool. Dish names changed accordingly and the intervention was called descriptive food names. For example, for NAHGAST I meals with the highest sustainability ratings, the amount of meat components was reduced, e.g. the amount of Nürnberger sausages from six to five, and for lentil stew $100 \mathrm{~g}$ of sausage was lowered to $75 \mathrm{~g}$. Another measure was substituting frozen vegetables with directly processed fresh, seasonal and regional vegetables and the use of fair-trade 
products such as fair-trade labelled coconut milk, rice or spices. These changes led to higher level of assessed sustainability. The descriptive names indicated relevant elements of sustainability improvements, e.g. for the potato bowl 'Westphalia meets Orient: spicy Münsterland tuber with chickpeas and arugula' (Westphalia and Münsterland are regions in Germany and signal regionality and short transportation distances; the environmental dimension of sustainability).

Daily meal sales data from each location was recorded to track changes in dish choices across interventions; socio-demographic data of cafeteria guests was not collected to minimise attentiveness in the real-world labs to a maximum.

\subsection{Data evaluation}

Sales data were evaluated using logistic regression analyses and predictive margins post estimation within Stata software (StataCorp LP, 2013). The use of nested logistic regressions (nlogit) was omitted, due to independence of alternatives (day of the week and cafeterias in different cities). The binary dependent variable 'choice' represents the choice of the most sustainable dish of each day $(0=$ competitor dish, $1=$ most sustainable dish of the day). For this purpose, sales were weighted by their frequency, as example, the chickpea curry was sold 47 times during a baseline Monday at the hospital staff cafeteria, making the dependent variable (baseline, Monday, hospital staff cafeteria, most sustainable dish) being weighted with $n=47$. The independent factor variables used, where each level of a variable is included by Stata as separate covariate/dummy (StataCorp LP, 2013), are for NAHGAST I: day (day of the week corresponds to the variant of the most sustainable dishes used 1 = Monday (chickpea curry), 2 = Tuesday (vegetable bowl), 3 = Wednesday (potato-/ pasta dish), $4=$ Thursday (vegetable stew with meat component), 5 = Friday (vegetarian Schnitzel / sausages)), intervention (variant of week of study: $0=$ baseline measurement, $1=$ counter position, $2=$ menu position, $3=$ descriptive names, $4=$ label on most sustainable dish, $5=$ label on all NAHGAST dishes, $6=$ label on all NAHGAST dishes and information) and cafeteria (distinction between participating cafeterias: $1=$ company $1,2=$ company 2, 3 = hospital, $4=$ school, $5=$ university) and for NAHGAST II: day (day of the week corresponds to the variant of the most sustainable dishes used $1=$ Monday (chickpea curry), 2 = Tuesday (rice bowl), $3=$ Wednesday (potato bowl), 4 = Thursday (vegetarian spaghetti Bolognese), 5 = Friday (chicken fricassee)), intervention (variant of week of study: $0=$ baseline measurement, $1=$ counter position, $2=$ menu position, $3=$ label on most sustainable dish and information) and cafeteria (distinction between participating cafeterias: $1=$ hospital, 2 = company, 3 = university). The assumption check for multicollinearity revealed no conspicuities (mean variance inflation factor NAHGAST I: 1.48, NAHGAST II: 1.49 (O’brien, 2007)). To compare all three 
intervention results with both baseline measurement weeks of NAHGAST II, we calculated an average of the baseline measurements (due to a difference of only 3\% of dishes sold between both baselines).

\section{Results}

\subsection{Results for NAHGAST I}

Out of 143,667 dishes being sold during the study period 78,151 were dishes from the NAHGAST menu, of which 20,049 had the highest daily sustainability rating; 74,415 dishes were included in our regression models. While the most sustainable dishes made up a third of the overall number of NAHGAST dishes, sale shares averaged only at $25 \%$, ranging from 12 to $37 \%$ depending on location (Appendix Table A1.) The efficacy of specific interventions varied with the counter position nudge being most successful in increasing sales of most sustainable dishes, confirming hypothesis one. Placing these dishes in positions that corresponded to highest sales during baseline measurements led an overall sales share of $31.6 \%$ (logistic regression: $\beta=0.313^{* * *}$, predictive margin: margin $=0.316^{* * *}$ ), a relative increase by $22.5 \%$ compared to the baseline. The second nudge, changed menu positions of most sustainable NAHGAST dishes, did not result in significant differences in sale shares $\left(\beta=0.052\right.$, margin $\left.=0.267^{* * *}\right)$. Accordingly, hypothesis two is rejected. Analysing the third intervention of using descriptive names revealed that this nudge decreased overall sales of the most sustainable dishes $\left(\beta=-0.105^{* * *}\right.$, margin $\left.=0.240^{* * *}\right)$. Thus, hypothesis three is rejected. Regarding label interventions, labels used without explanatory information and only on the most sustainable dishes did not lead to significant differences in sale shares $\left(\beta=-0.011\right.$, margin $\left.=0.256^{* * *}\right)$, while displaying labels for all NAHGAST dishes resulted in decreased sales of the most sustainable dishes $\left(\beta=-0.116^{* * *}\right.$, margin $\left.=0.238^{* * *}\right)$, rejecting hypothesis four. Providing more explanatory information regarding the label for all labelled NAHGAST dishes did also not lead to significant differences to the baseline $(\beta=0.013$, margin $=0.260 * * *)$. Therefore, also hypothesis five is rejected. For further logistic regression results for each location see Appendix Table A2.

With regard to daily sales, we found strong differences in popularity between most sustainable and competitor dishes, as well as between the different real-world labs (Appendix Table A3), which confirms hypothesis six. While overall in the baseline the potato and pasta dishes on Wednesdays (margin $=0.392 * * *$ ) and the vegetarian schnitzel and sausages on Fridays (margin $=0.365 * * *)$ were specifically favoured, sales of the other three most sustainable dishes of the day remained below $33 \%$ (chickpea curry: margin $=0.198^{* * *}$, vegetable bowl: margin $=0.185^{* * *}$, vegetable stew: margin $\left.0.172 * * *\right)$. While for the counter position, menu position and label $\&$ information nudges sales increased compared to the baseline for each of the five intervention days 
and therefore for each of the most sustainable dishes on offer, sales were consistently lower on all intervention days for descriptive names, and both label nudges, therefore rejecting hypothesis seven. Thus, competitor dishes also have to be taken into consideration when implementing nudging approaches.

\subsection{Results for NAHGAST II}

Of 15,741 dishes being sold overall, 3,381 were assessed as most sustainable dishes of the day; 15,235 dishes were included in our regression models. Overall, all three nudges had a positive effect on most sustainable dish sales (see Appendix Table A4). Compared to our baseline measurement weeks with a 19.4\% share of the most sustainable dishes, counter position nudges increased their sales but overall, not significantly $(\beta=0.091$, margin $=0.209^{* * *}$ ). Having a closer look at Appendix Table A5 and the comparison of single canteens, results reveal that a particularity of the hospital staff cafeteria, a considerable shorter counter situation compared to all other canteens, is reflected in the data and was confirmed as relevant fact in discussions with the practitioners. Due to only a single short food counter for food distribution, the counter position nudge decreased sales in this cafeteria $(\beta=-0.093$, margin $=0.199 * * *)$. Spatial condition can hence influence impact of nudges and herby confirms hypothesis six regarding setting-specific differences.

Overall, menu position nudges $\left(\beta=0.120^{*}\right.$, margin $\left.=0.214^{* * *}\right)$ increased sales of most sustainable dishes significantly, mainly because of the hospital staff cafeteria $\left(\beta=0.267^{*}\right.$, margin $\left.=0.262^{* * *}\right)$, confirming hypothesis two for NAHGAST II. However, hypothesis two would be rejected if the hospital staff cafeteria would be excluded due to different infrastructural conditions (see Figure 1). The label nudge with explanatory information $\left(\beta=0.173^{* *}\right.$, margin $\left.=0.223^{* * *}\right)$ also increased dish sales significantly, conforming hypothesis five for NAHGAST II.

Among most sustainable dishes, the chickpea curry (base, margin $=0.239 * * *$ ) and the vegetarian spaghetti Bolognese $\left(\beta=-0.075\right.$, margin $\left.=0.225^{* * *}\right)$ were most favoured by guests. The potato bowl $\left(\beta=-0.139^{*}\right.$, $\operatorname{margin}=0.214 * * *)$, the rice bowl $(\beta=-0.262 * * *$, margin $=0.194 * * *)$ and the chicken fricassee $(\beta=-0.688 * * *$, margin $\left.=0.136^{* * *}\right)$, however, were less popular. Comparing participating cafeterias, the most sustainable dishes were most popular at the hospital staff cafeteria (base, margin $=0.232 * * *$ ) followed by the university cafeteria $\left(\beta=-0.175^{* * *}\right.$, margin $\left.=0.203^{* * *}\right)$ and the company cafeteria $(\beta=-0.180 * *$, $\operatorname{margin}=0.202 * * *)$. Similar to NAHGST I, all five most sustainable dishes were less favoured than their daily competitors; daily shares between $12.6 \%$ (chicken fricassee) and 22.3\% (chickpea curry) (see Appendix Table A6). For each of the three tested nudges - counter position, menu position and label \& information - each most sustainable dish 
of the day increased in sales compared to baseline measurements. This confirms the results of NAHGAST 1 regarding the rejection of hypothesis 7.

\subsection{Comparing insights of the two project iterations}

Figure 1 presents a comparison of the results from NAHGAST I and NAHGAST II. Due to the differing infrastructural conditions in the hospital staff cafeteria of NAHGAST II mentioned above, this data was excluded from the comparison (see Appendix Table A7). The type 1 nudge 'counter position' increased sales of the most sustainable dishes in both project iterations significantly, confirming hypothesis one. The type 1 nudge 'menu position' also increased sales but not significantly, therefore hypothesis two is rejected. Overall, there is a potential of system 1 nudges to stimulate sustainable out-of-home consumer choices. The successful application of type 2 nudges seems to be harder to achieve. As figure 1 displays, in NAHGAST I, the target dish sales decreased significantly when 'descriptive names' changed, decreased (in)significantly with the type 2 nudge 'labels without information' applied on one/all NAHGAST dishes and had no significant effect when additional information was given. In NAHGAST II, however, 'label plus information' nudges increased sales, making them another possibly effective intervention for practitioners. It has to be noted that the 'label plus information' nudge in NAHGAST II achieved the strongest positive deviation from our baseline measurement.

Figure 1. Comparison of intervention results of NAHGAST I \& II.

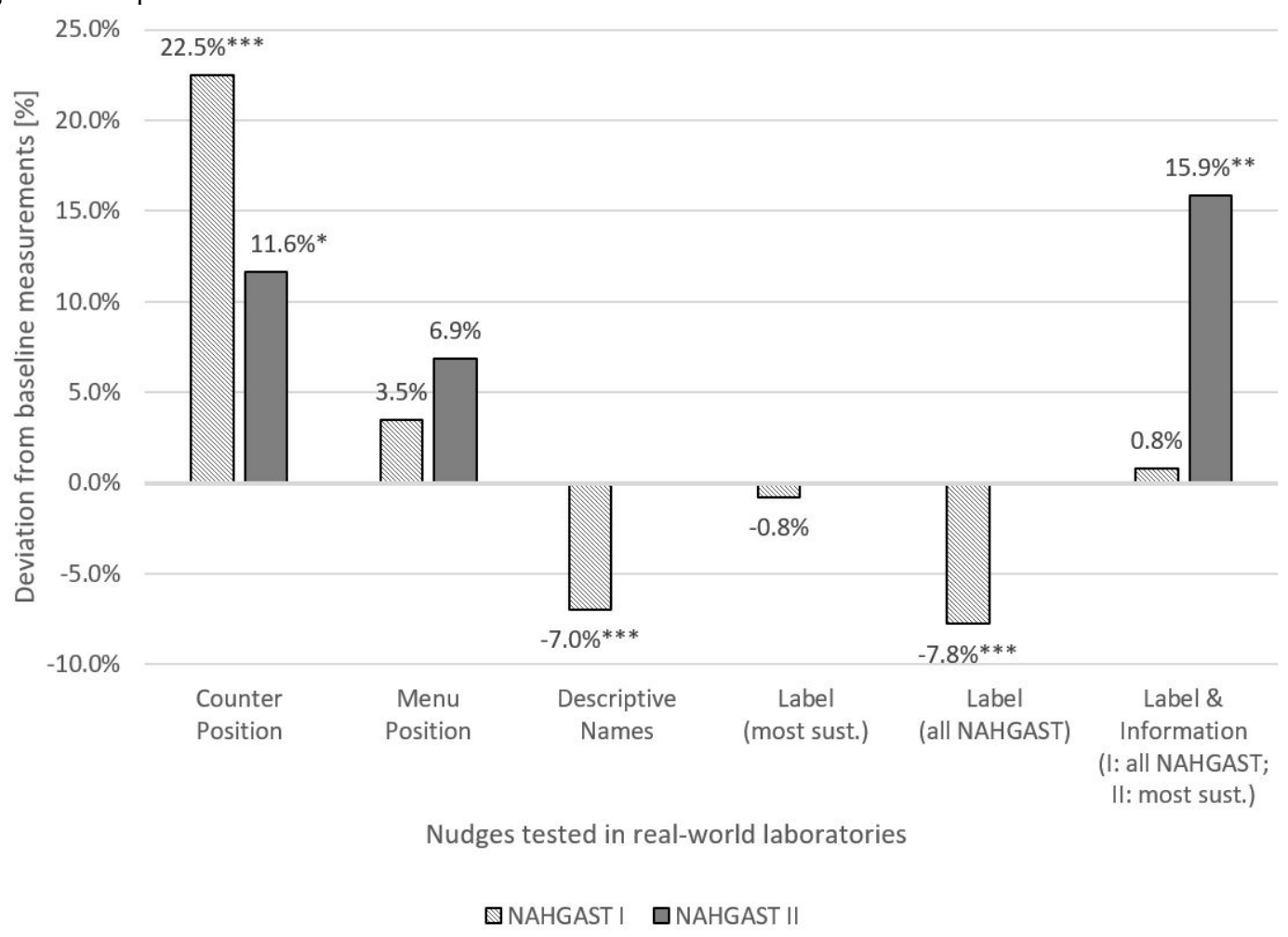

Note: $* * * \mathrm{p}<0.001, * * \mathrm{p}<0.01, * \mathrm{p}<0.05$. 


\section{Discussion}

\subsection{Data limitations}

We tested our hypotheses in real-world settings of German workplace and school cafeterias to observe pure human behaviour as accurately as possible. Strong collaboration with the practice partners and harmonisation of interventions and meals between them was necessary to obtain usable data for analysis. However, despite specific communication such as the provision of visual information indicating the required dish positioning or required labels, wrong positioning occurred (e.g. in iteration II, due to a lack of practical feasibility and the distance to power outlets for dish warmers). Further, although all locations agreed on the harmonised menu, sustainability ratings differed due to cafeteria-specific recipes (e.g. in iteration I, the stew recipes differed regarding the inclusion of specific meat components (sausage, smoked meat, ground pork). Another confounding factor was the amount and kind of dishes offered besides the three harmonised main dishes (see Table 3). These competitor dishes varied from one intervention week to the other. For example, while the three NAHGAST dishes were served in the same combination in certain regularity, e.g. in spring, asparagus was offered as competitor dish of the week and roast goose in autumn. Unfortunately, it was impossible for the partners in NAHGAST I to also control for the competitor dishes. Learning from these limitations we improved the study design and controlled for dishes offered. Other factors causing missing data or incomparable data in the first project phase were for example public holidays, a service restricted to four of five weekdays at the school cafeteria, or the delayed data collection at company cafeteria 2 leading to different seasonal conditions. For the second project iteration, missing data could considerably be reduced. However, data is partially missing for the first and fifth day of the first baseline measurement week at the hospital staff cafeteria and at the company cafeteria on Fridays due to issues with dish positioning.

Regarding plausible time- and consumption trends possibly influencing consumer preferences, awareness and involvement in a sustainable diet, "Fridays for Future" strikes might be of particular relevance. Right after the first project iteration in January 2019 and thus before the second, the "Fridays for Future" strikes began taking place in Germany (FridaysForFuture, 2019). The movement itself began in August 2018 (FridaysForFuture, 2019). Increased media coverage of climate change might have increased overall awareness for sustainability issues in general in the second iteration compared to the first. This potentially affects the behaviour disclosed in the second project iteration and might explain the differences in the effects of system 2-nudges in particular. 


\subsection{Effectiveness of the different nudging interventions}

Using a real-world lab standardised empirical approach (similar intervention design across locations, including a harmonised menu) we described nudging interventions belonging to the area of physical environment and the choice making phase conducted at eight representative locations over two project iterations, 2016/2017 and 2019/2020. During the first data collection phase, only the counter position nudge led to significant increases in sales of most sustainable NAHGAST dishes. Throughout the second project phase, on average all nudging interventions increased most sustainable dish sales. There, the label nudge combined with an explanation had the biggest positive impact.

Answering our hypotheses and excluding the hospital staff cafeteria in the second iteration due to infrastructural obstacles, (i) counter position nudges significantly increased most sustainable dish sales (first hypothesis confirmed). The effectiveness of menu position nudges, hypothesis (ii), could not be confirmed. Hypothesis (iii), descriptive names as nudge increase sales of sustainable dishes is rejected. Displaying a label informing about sustainability performance of a dish without giving additional background information regarding the label (hypothesis iv) does not increase sustainable dish sales. Hypothesis (v), label plus information nudges are effective, is only confirmed for the second project period. Considering the significant effects of different situational and setting specific conditions between practitioners, we can confirm the sixth hypothesis. This became most obvious in the hospital canteen where the counter was simply not long enough to successfully implement the counter nudge. Therefore, to ensure successful implementation of nudges, they should be adjusted to their respective environment. Hypothesis (vii) is rejected since nudges' effectiveness was independent from weekdays. However, competitor dishes are relevant factors influencing nudge performance. The NAHGAST I results reveal that competitor dishes diminished nudging effects somewhat by 'cannibalising' the overall daily sales share of the most sustainable dishes of the day. Sales shares of only two out of ten of the most sustainable dishes during both project iterations were above $33 \%$. Therefore, 'top runners' such as meatballs or schnitzel should be offered consciously besides targeted sustainable dishes to not diminish sustainable dishes sales.

The differences found in the effects of some nudges between both project iterations might be the result of the adjusted survey design in NAHGAST II and/or due to changes within the societal environment we did not control for. Concerning the advanced survey design, in the second iteration measurement weeks did not contain public holidays, seasonal effects were strictly controlled for, only three daily dishes were available during each intervention week to reduce the overall choice options to the set of harmonised dishes across all cafeterias, and the baseline data pool was enlarged (two instead of one baseline measurement week). In particular the broader 
database to which the intervention data is compared to should balance out possible effects of a single, extraordinary event during baseline measurement. These improvements might explain the different results of the type 1 nudges between the project iterations. However, they do not provide an explanation for the different performances of the type 2 nudge label plus information in NAHGAST II. Hence, other factors such as personal characteristics of guests and their value system might have influenced final results. We did not ask guests for their personal opinion or attitude nor preferences but only observed their behaviour. Therefore, we are not able to differentiate between those with a higher interest in food and sustainable consumption and others with lower involvement or different value systems. Regarding surrounding societal environmental factors, the emergence of the Fridays for Future movement might be of relevance. As elaborated in the introduction, increasing involvement in food choice might be a key to provoking more sustainable food choices. The media coverage of Fridays for Future strikes could have fostered higher involvement in food choices out of home. Higher involvement then could have facilitated processing of displayed information, evoking more sustainable dish choice. Hence, the impact of involvement for the successful applicability of labelling information as system 2 nudges should be an issue of further investigation.

To advance future research, nudge interventions should be implemented over longer timeframes in order to measure long-term effects of nudges on out-of-home consumer choices (Winkler et al., 2018). Further, a harmonised menu should cover all available dishes. Regarding our sustainability label, future research could uncover distinct consumer preferences regarding the different dimensions of sustainability displayed. It might be of relevance for practitioners whether consumers - when looking at a comprehensive label - choose their dishes based mainly on environmental, health or fairness aspects or a combination thereof (Langen et al., 2017).

Nudge interventions can be used nearly at each point in time of the consumer choice process (from choosing a dish, serving, eating, cleaning up, and paying) (see Appendix Figure A1). Moreover, they can target the different levels of individual factors, social and physical environment. Thus, numerous significant leverage points can be created and be adapted to each thinkable cafeteria to increase guests' preferences for sustainable meals (for an overview see Langen (2018)). Our approach to compare the effects of the same intervention in different settings and the effect of different, sequential nudging interventions in the same setting reveals that some nudge interventions are a useful approach for the out-of-home catering sector to guide food choices towards more sustainable meals. Overall, our findings show that nudges allow small, low-cost and non-invasive changes to the choice architecture in the out-of-home catering sector. To be most effective we recommend monitoring all nudges implemented with regard to location-specific settings and situational conditions. 


\subsection{Conclusions}

We successfully compared different nudging interventions in a systematic way across settings to investigate potential consistent pattern of evidence and hence are able to add to the existing literature. Results reveal that one type 1 nudge always works: the counter position. This was the intervention practitioners found simplest to implement. Labelling sustainable dishes and giving respective explanations successfully altered consumer choices towards sustainable dishes in the second iteration. This type 2 nudge seems to be suited in combination with awareness raising and other means to increase guest involvement in sustainable food consumption.

Further, our study shows that the chosen real-world laboratories research approach requires a lot from practitioners as well as scientists. Practical doing of cooks and staff in cafeterias is not per se suited to produce accurate scientific data needed to analyse precisely and without additional constraints. Great willingness to understand each other and to work together in a transdisciplinary way is needed to bring such projects to fruition. Time for adjustments is needed, funding institutions' openness for such transdisciplinary experiments is fundamental. Overall, the particular challenges have to be taken into account whenever real-world lab projects are planned and conducted.

Author Contributions: NL: conceptualisation, methodology, investigation, validation, resources, writing original draft, writing - review \& editing, supervision, project administration, funding acquisition.

PO: conceptualisation, methodology, investigation, data curation, software, formal analysis, validation, writing original draft

FS: conceptualisation, project administration

SF: conceptualisation, project administration

TE: conceptualisation

MS: conceptualisation

KD: writing original draft

$\mathrm{KB}$ : conceptualisation

HR: conceptualisation

PT: conceptualisation

Funding: This research was funded by the German Federal Ministry of Education and Research - BMBF - FONA, grant number 01UT1409B and 01UT1902B.

Acknowledgments: The authors would like to thank all researchers involved in the NAHGAST project, specifically Christine Kanand (University of Applied Sciences Münster). We thank our participating cafeterias for their support and their willingness to implement our nudge interventions. We also thank Antje Risius (Georg-August-Universität Göttingen), Anneleen Van Kerckhove (Universiteit Gent), Jan Michael Bauer (Copenhagen Business School), Ruben Korenke (Technische Universität Berlin) and Robin Jadkowski (Technische Universität Berlin) for their feedback on methodological issues. The authors gratefully acknowledge the support by the anonymous reviewers.

Declaration of interest: The authors declare no competing interests.

Data availability: Additional information and intervention statistics are available upon request from the authors. 


\section{Appendix}

Appendix Table A1. NAHGAST I results - Logistic Regression and predictive margins (dependent variable (DV): Choice of most sustainable dish, independent variable (IV): Intervention variant, Day of the week, cafeteria type).

\begin{tabular}{|c|c|c|c|c|}
\hline Choice of most sustainable dish & Coefficient & $\begin{array}{l}\text { Standard } \\
\text { Error }\end{array}$ & Margins & $\begin{array}{r}\text { Standard } \\
\text { Error }\end{array}$ \\
\hline \multicolumn{5}{|l|}{ Intervention } \\
\hline Baseline Measurement & 0 & (base) & $0.258 * * *$ & 0.003 \\
\hline Counter Position & $0.313 * * *$ & 0.038 & $0.316 * * *$ & 0.006 \\
\hline Menu Position & 0.052 & 0.048 & $0.267 * * *$ & 0.008 \\
\hline Descriptive Names & $-0.105 * * *$ & 0.029 & $0.240 * * *$ & 0.004 \\
\hline Label (most sustainable dish) & -0.011 & 0.027 & $0.256^{* * *}$ & 0.003 \\
\hline Label (all NAHGAST dishes) & $-0.116 * * *$ & 0.034 & $0.238 * * *$ & 0.005 \\
\hline $\begin{array}{l}\text { Label \& Information } \\
\text { (all NAHGAST dishes) }\end{array}$ & 0.013 & 0.027 & $0.260 * * *$ & 0.004 \\
\hline \multicolumn{5}{|l|}{ Day } \\
\hline $\begin{array}{l}\text { Monday } \\
\text { (Chickpea curry) }\end{array}$ & 0 & (base) & $0.198 * * *$ & 0.003 \\
\hline $\begin{array}{l}\text { Tuesday } \\
\text { (Vegetable bowl) }\end{array}$ & $-0.083 * *$ & 0.030 & $0.185 * * *$ & 0.003 \\
\hline $\begin{array}{l}\text { Wednesday } \\
\text { (Potato/ pasta dish) }\end{array}$ & $1.006 * * *$ & 0.028 & $0.392 * * *$ & 0.004 \\
\hline $\begin{array}{l}\text { Thursday } \\
\text { (Vegetable stew with meat component) }\end{array}$ & $-0.176^{* * *}$ & 0.029 & $0.172 * * *$ & 0.003 \\
\hline $\begin{array}{l}\text { Friday } \\
\text { (Vegetarian schnitzel / sausages) }\end{array}$ & $0.887 * * *$ & 0.026 & $0.365 * * *$ & 0.004 \\
\hline \multicolumn{5}{|l|}{ Cafeteria } \\
\hline Company 1 & 0 & (base) & $0.124 * * *$ & 0.002 \\
\hline Company 2 & $1.040 * * *$ & 0.036 & $0.277 * * *$ & 0.005 \\
\hline Hospital & $0.793 * * *$ & 0.037 & $0.233 * * *$ & 0.005 \\
\hline School $^{\text {a }}$ & $1.495 * * *$ & 0.033 & $0.371 * * *$ & 0.005 \\
\hline University & $1.206^{* * *}$ & 0.027 & $0.310 * * *$ & 0.003 \\
\hline constant & $-2.362 * * *$ & 0.036 & - & - \\
\hline Number of observations & 74,415 & & & \\
\hline Pseudo $\mathrm{R}^{2}$ & 0.0714 & & & \\
\hline Log likelihood & $-39,402.08$ & & & \\
\hline
\end{tabular}

Note: ' Interventions 'counter position' and 'menu position' tested together. $* * * \mathrm{p}<0.001, * * \mathrm{p}<0.01, * \mathrm{p}<0.05$. 
Appendix Table A2. NAHGAST I results - Logistic Regression and predictive margins for each cafeteria (dependent variable (DV): Choice of most sustainable dish, independent variable (IV): Intervention variant, Day of the week).

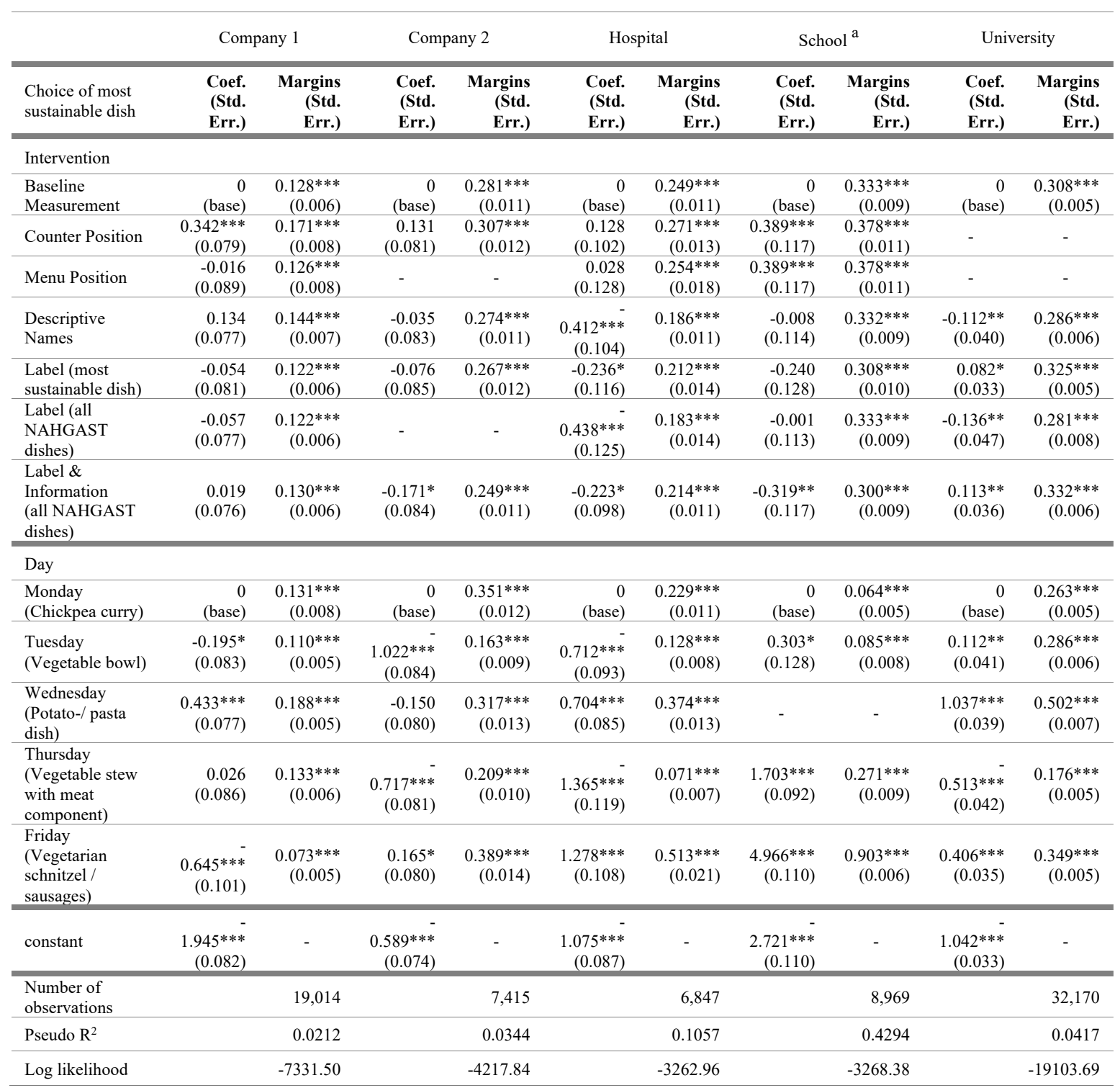

Note: ${ }^{a}$ Interventions 'counter position' and 'menu position' tested together.

$* * * \mathrm{p}<0.001, * * \mathrm{p}<0.01, * \mathrm{p}<0.05$.

Logistic regression results revealed that significant increases in sales from the counter position nudge occurred only at company cafeteria 1 and the school cafeteria, while for company cafeteria 2 as well as the hospital staff cafeteria sales data increased, yet not significantly. Regarding the menu position nudge, comparability across settings was limited. Company cafeteria 1 showed a non-significant decrease, the hospital staff cafeteria a non-significant increase, and the school cafeteria a significant increase in combination with the counter position nudge. While the descriptive names nudge nearly gained significant positive influence at company cafeteria 1 , it decreased sales at company cafeteria 2 , the school cafeteria, and particularly at both the hospital staff and university cafeteria. This suggests that the wording of dish names in itself might influence sales and hence should be pretested in advance (Ohlhausen and Langen, 2020). Similarly, we found mixed effects of the first label intervention only signalling the most sustainable dishes. Four out of five cafeterias recorded a decrease in their sales, only having a positive impact at the university cafeteria. Instead, when labelling all NAHGAST dishes, logistic regression results were more consistent yet still ambiguous. All four cafeterias sold less of the dishes with the highest sustainability ratings, but company cafeteria 1 recording non-significant negative effects and showing nearly no effect at the school cafeteria. Similar results to the first label intervention were achieved with the addition of extra information on the label. Regression results revealed a significant negative effect at company cafeteria 2, the hospital staff- and school cafeterias. The other two locations increased their sales of most sustainable dishes, with the effect being significant only for the university cafeteria. 
Appendix Table A3. Results for NAHGAST I - Predictive margins for dish sale shares.

\begin{tabular}{|c|c|c|c|c|c|c|c|}
\hline & $\begin{array}{l}\text { Baseline } \\
\text { Measure } \\
\text { ment }\end{array}$ & $\begin{array}{l}\text { Counter } \\
\text { Position }\end{array}$ & $\begin{array}{l}\text { Menu } \\
\text { Position }\end{array}$ & $\begin{array}{l}\text { Descripti } \\
\text { ve Names }\end{array}$ & $\begin{array}{l}\text { Label } \\
\text { (most } \\
\text { sust.) }\end{array}$ & $\begin{array}{l}\text { Label } \\
\text { (all) }\end{array}$ & $\begin{array}{l}\text { Label \& } \\
\text { Informati } \\
\text { on } \\
\text { (all) }\end{array}$ \\
\hline & $\begin{array}{l}\text { Margin } \\
\text { (Std. } \\
\text { Err.) }\end{array}$ & $\begin{array}{r}\text { Margins } \\
\text { (Std. } \\
\text { Err.) }\end{array}$ & $\begin{array}{r}\text { Margins } \\
\text { (Std. } \\
\text { Err.) }\end{array}$ & $\begin{array}{r}\text { Margins } \\
\text { (Std. } \\
\text { Err.) }\end{array}$ & $\begin{array}{r}\text { Margins } \\
\text { (Std. } \\
\text { Err.) }\end{array}$ & $\begin{array}{r}\text { Margins } \\
\text { (Std. } \\
\text { Err.) }\end{array}$ & $\begin{array}{r}\text { Margins } \\
\text { (Std. } \\
\text { Err.) }\end{array}$ \\
\hline $\begin{array}{l}\text { Monday } \\
\text { (Chickpea curry) }\end{array}$ & $\begin{array}{l}0.198 * * * \\
(0.004)\end{array}$ & $\begin{array}{l}0.250 * * * \\
(0.007)\end{array}$ & $\begin{array}{l}0.206^{* * *} \\
(0.007)\end{array}$ & $\begin{array}{l}0.182 * * * \\
(0.004)\end{array}$ & $\begin{array}{l}0.196 * * * \\
(0.004)\end{array}$ & $\begin{array}{l}0.181 * * * \\
(0.005)\end{array}$ & $\begin{array}{l}0.200 * * * \\
(0.004)\end{array}$ \\
\hline $\begin{array}{l}\text { Tuesday } \\
\text { (Vegetable bowl) }\end{array}$ & $\begin{array}{l}0.185^{* * *} \\
(0.004)\end{array}$ & $\begin{array}{l}0.236^{* * *} \\
(0.007)\end{array}$ & $\begin{array}{l}0.193 * * * \\
(0.007)\end{array}$ & $\begin{array}{l}0.171^{* * *} \\
(0.004)\end{array}$ & $\begin{array}{l}0.184 * * * \\
(0.004)\end{array}$ & $\begin{array}{l}0.169 * * * \\
(0.005)\end{array}$ & $\begin{array}{l}0.188^{* * * *} \\
(0.004)\end{array}$ \\
\hline $\begin{array}{l}\text { Wednesday } \\
\text { (Potato/ pasta } \\
\text { dish) }\end{array}$ & $\begin{array}{l}0.392 * * * \\
(0.006)\end{array}$ & $\begin{array}{l}0.464 * * * \\
(0.008)\end{array}$ & $\begin{array}{l}0.404 * * * \\
(0.010)\end{array}$ & $\begin{array}{l}0.369 * * * \\
(0.006)\end{array}$ & $\begin{array}{l}0.390 * * * \\
(0.006)\end{array}$ & $\begin{array}{l}0.367 * * * \\
(0.007)\end{array}$ & $\begin{array}{l}0.395 * * * \\
(0.006)\end{array}$ \\
\hline $\begin{array}{l}\text { Thursday } \\
\text { (Vegetable stew } \\
\text { with meat } \\
\text { component) }\end{array}$ & $\begin{array}{l}0.172 * * * \\
(0.004)\end{array}$ & $\begin{array}{l}0.220 * * * \\
(0.006)\end{array}$ & $\begin{array}{l}0.180 * * * \\
(0.007)\end{array}$ & $\begin{array}{l}0.158 * * * \\
(0.004)\end{array}$ & $\begin{array}{l}0.171 * * * \\
(0.004)\end{array}$ & $\begin{array}{l}0.157 * * * \\
(0.005)\end{array}$ & $\begin{array}{l}0.174 * * * \\
(0.004)\end{array}$ \\
\hline $\begin{array}{l}\text { Friday } \\
\text { (Vegetarian } \\
\text { schnitzel / } \\
\text { sausages) }\end{array}$ & $\begin{array}{l}0.365^{* * *} \\
(0.005)\end{array}$ & $\begin{array}{l}0.437 * * * \\
(0.008)\end{array}$ & $\begin{array}{l}0.377 * * * \\
(0.010)\end{array}$ & $\begin{array}{l}0.343 * * * \\
(0.006)\end{array}$ & $\begin{array}{l}0.363 * * * \\
(0.005)\end{array}$ & $\begin{array}{l}0.341 * * * \\
(0.007)\end{array}$ & $\begin{array}{l}0.369 * * * \\
(0.006)\end{array}$ \\
\hline
\end{tabular}

Note: $* * * \mathrm{p}<0.001, * * \mathrm{p}<0.01, * \mathrm{p}<0.05$. 
Appendix Table A4. Results for NAHGAST II - Logistic Regression and predictive margins (dependent variable (DV): Choice of most sustainable dish, independent variable (IV): Intervention variant, Day of the week, cafeteria type).

\begin{tabular}{|c|c|c|c|c|}
\hline Choice of most sustainable dish & Coefficient & $\begin{array}{r}\text { Standard } \\
\text { Error }\end{array}$ & Margins & $\begin{array}{r}\text { Standard } \\
\text { Error }\end{array}$ \\
\hline \multicolumn{5}{|l|}{ Intervention } \\
\hline Baseline Measurement & 0 & (base) & $0.194 * * *$ & 0.006 \\
\hline Counter Position & 0.091 & 0.055 & $0.209 * * *$ & 0.007 \\
\hline Menu Position & $0.120 *$ & 0.054 & $0.214 * * *$ & 0.006 \\
\hline $\begin{array}{l}\text { Label \& Information } \\
\text { (most sustainable dish) }\end{array}$ & $0.173 * *$ & 0.059 & $0.223 * * *$ & 0.008 \\
\hline \multicolumn{5}{|l|}{ Day } \\
\hline $\begin{array}{l}\text { Monday } \\
\text { (Chickpea curry) }\end{array}$ & 0 & (base) & $0.239 * * *$ & 0.008 \\
\hline $\begin{array}{l}\text { Tuesday } \\
\text { (Rice bowl) }\end{array}$ & $-0.262 * * *$ & 0.059 & $0.194 * * *$ & 0.007 \\
\hline $\begin{array}{l}\text { Wednesday } \\
\text { (Potato bowl) }\end{array}$ & $-0.139 *$ & 0.059 & $0.214^{* * *}$ & 0.007 \\
\hline $\begin{array}{l}\text { Thursday } \\
\text { (Vegetarian spaghetti Bolognese) }\end{array}$ & -0.075 & 0.059 & $0.225^{* * *}$ & 0.007 \\
\hline $\begin{array}{l}\text { Friday } \\
\text { (Chicken fricassee) }\end{array}$ & $-0.688 * * *$ & 0.084 & $0.136^{* * *}$ & 0.009 \\
\hline \multicolumn{5}{|l|}{ Cafeteria } \\
\hline Hospital & 0 & (base) & $0.232 * * *$ & 0.008 \\
\hline Company & $-0.180 * *$ & 0.067 & $0.202 * * *$ & 0.008 \\
\hline University & $-0.175^{* * *}$ & 0.050 & $0.203 * * *$ & 0.004 \\
\hline constant & $-1.113^{* * *}$ & 0.066 & - & - \\
\hline Number of observations & 15,235 & & & \\
\hline Pseudo $\mathrm{R}^{2}$ & 0.0067 & & & \\
\hline Log likelihood & $-7,755.09$ & & & \\
\hline
\end{tabular}

Note: $* * * \mathrm{p}<0.001, * * \mathrm{p}<0.01, * \mathrm{p}<0.05$. 
Appendix Table A5. NAHGAST II results - Logistic Regression and predictive margins for each cafeteria (dependent variable (DV): Choice of most sustainable dish, independent variable (IV): Intervention variant, Day of the week).

\begin{tabular}{|c|c|c|c|c|c|c|}
\hline \multirow[b]{2}{*}{$\begin{array}{l}\text { Choice of most sustainable } \\
\text { dish }\end{array}$} & \multicolumn{2}{|c|}{ Hospital } & \multicolumn{2}{|c|}{ Company } & \multicolumn{2}{|c|}{ University } \\
\hline & $\begin{array}{l}\text { Coef. } \\
\text { (Std. } \\
\text { Err.) }\end{array}$ & $\begin{array}{r}\text { Margins } \\
\text { (Std. } \\
\text { Err.) }\end{array}$ & $\begin{array}{l}\text { Coef. } \\
\text { (Std. } \\
\text { Err.) }\end{array}$ & $\begin{array}{r}\text { Margins } \\
\text { (Std. } \\
\text { Err.) }\end{array}$ & $\begin{array}{l}\text { Coef. } \\
\text { (Std. } \\
\text { Err.) }\end{array}$ & $\begin{array}{r}\text { Margins } \\
\text { (Std. } \\
\text { Err.) }\end{array}$ \\
\hline \multicolumn{7}{|l|}{ Intervention } \\
\hline Baseline Measurement & $\begin{array}{r}0 \\
\text { (base) }\end{array}$ & $\begin{array}{r}0.214 * * * \\
(0.014)\end{array}$ & $\begin{array}{r}0 \\
\text { (base) }\end{array}$ & $\begin{array}{r}0.200 * * * \\
(0.017)\end{array}$ & $\begin{array}{r}0 \\
\text { (base) }\end{array}$ & $\begin{array}{r}0.186 * * * \\
(0.007)\end{array}$ \\
\hline Counter Position & $\begin{array}{r}-0.093 \\
(0.124)\end{array}$ & $\begin{array}{r}0.199 * * * \\
(0.014)\end{array}$ & $\begin{array}{r}0.105 \\
(0.150)\end{array}$ & $\begin{array}{r}0.217 * * * \\
(0.018)\end{array}$ & $\begin{array}{l}0.146^{*} \\
(0.068)\end{array}$ & $\begin{array}{r}0.209 * * * \\
(0.008)\end{array}$ \\
\hline Menu Position & $\begin{array}{l}0.267 * \\
(0.116)\end{array}$ & $\begin{array}{r}0.262 * * * \\
(0.015)\end{array}$ & $\begin{array}{r}0.085 \\
(0.147)\end{array}$ & $\begin{array}{r}0.214 * * * \\
(0.017)\end{array}$ & $\begin{array}{r}0.083 \\
(0.068)\end{array}$ & $\begin{array}{r}0.199 * * * \\
(0.008)\end{array}$ \\
\hline $\begin{array}{l}\text { Label \& Information } \\
\text { (most sustainable dish) }\end{array}$ & $\begin{array}{r}0.144 \\
(0.122)\end{array}$ & $\begin{array}{r}0.240 * * * \\
(0.016) \\
\end{array}$ & $\begin{array}{r}0.111 \\
(0.144)\end{array}$ & $\begin{array}{r}0.218 * * * \\
(0.016) \\
\end{array}$ & $\begin{array}{r}0.213 * * \\
(0.077)\end{array}$ & $\begin{array}{r}0.220 * * * \\
(0.010)\end{array}$ \\
\hline \multicolumn{7}{|l|}{ Day } \\
\hline $\begin{array}{l}\text { Monday } \\
\text { (Chickpea curry) }\end{array}$ & $\begin{array}{r}0 \\
\text { (base) }\end{array}$ & $\begin{array}{r}0.287 * * * \\
(0.017)\end{array}$ & $\begin{array}{r}0 \\
\text { (base) }\end{array}$ & $\begin{array}{r}0.234 * * * \\
(0.017)\end{array}$ & $\begin{array}{r}0 \\
\text { (base) }\end{array}$ & $\begin{array}{r}0.224 * * * \\
(0.009)\end{array}$ \\
\hline $\begin{array}{l}\text { Tuesday } \\
\text { (Rice bowl) }\end{array}$ & $\begin{array}{r}-0.364 * * \\
(0.126)\end{array}$ & $\begin{array}{r}0.219 * * * \\
(0.016)\end{array}$ & $\begin{array}{r}-0.770 * * * \\
(0.158)\end{array}$ & $\begin{array}{r}0.124 * * * \\
(0.014)\end{array}$ & $\begin{array}{l}-0.120 \\
(0.075)\end{array}$ & $\begin{array}{r}0.204 * * * \\
(0.008)\end{array}$ \\
\hline $\begin{array}{l}\text { Wednesday } \\
\text { (Potato bowl) }\end{array}$ & $\begin{array}{r}-0.477 * * * \\
(0.128)\end{array}$ & $\begin{array}{r}0.200 * * * \\
(0.015)\end{array}$ & $\begin{array}{r}-0.052 \\
(0.138)\end{array}$ & $\begin{array}{r}0.224 * * * \\
(0.017)\end{array}$ & $\begin{array}{r}-0.054 \\
(0.075)\end{array}$ & $\begin{array}{r}0.215 * * * \\
(0.009)\end{array}$ \\
\hline $\begin{array}{l}\text { Thursday } \\
\text { (Vegetarian spaghetti } \\
\text { Bolognese) }\end{array}$ & $\begin{array}{r}-0.392 * * \\
(0.128)\end{array}$ & $\begin{array}{r}0.214 * * * \\
(0.016)\end{array}$ & $\begin{array}{r}0.217 \\
(0.138)\end{array}$ & $\begin{array}{r}0.275^{* * *} * \\
(0.020)\end{array}$ & $\begin{array}{r}-0.042 \\
(0.075)\end{array}$ & $\begin{array}{r}0.217 * * * \\
(0.009)\end{array}$ \\
\hline $\begin{array}{l}\text { Friday } \\
\text { (Chicken fricassee) }\end{array}$ & $\begin{array}{r}-0.332 * \\
(0.137)\end{array}$ & $\begin{array}{r}0.224 * * * \\
(0.019)\end{array}$ & - & - & $\begin{array}{r}-0.956^{* * *} \\
(0.114)\end{array}$ & $\begin{array}{r}0.100 * * * \\
(0.009)\end{array}$ \\
\hline constant & $\begin{array}{r}-0.997 * * * \\
(0.113)\end{array}$ & - & $\begin{array}{r}-1.264 * * * \\
(0.132)\end{array}$ & - & $\begin{array}{r}-1.341 * * * \\
(0.068)\end{array}$ & - \\
\hline Number of observations & & 3,188 & & 2,287 & & 9,760 \\
\hline Pseudo $\mathrm{R}^{2}$ & & 0.0079 & & 0.0190 & & 0.0105 \\
\hline Log likelihood & & -1702.98 & & -1160.45 & & -4850.41 \\
\hline
\end{tabular}

Counter position nudges decreased most sustainable dish sales at the hospital staff cafeteria $(\beta=-0.093$, margin $\left.=0.199^{* * *}\right)$, but not significantly. This might have resulted from only one short food counter being available for food distribution, making the menu position nudge more effective $\left(\beta=0.267^{*}\right.$, margin $\left.=0.262^{* * *}\right)$. Label nudges increased most sustainable dish sales $\left(\beta=0.144\right.$, margin $\left.=0.240^{* * *}\right)$. The chickpea curry prevailed (base, margin $=0.287^{* * *}$ ) as a favourite among all most sustainable dishes. In contrast, at the company cafeteria all three nudges tested had nearly equal effects on most sustainable dish sales: counter position nudges led to a relative increase by $9 \%\left(\beta=0.105\right.$, margin $\left.=0.217^{* * *}\right)$, menu position nudges by $7 \%\left(\beta=0.085\right.$, margin $\left.=0.214^{* * *}\right)$ and label nudges by $9 \%\left(\beta=0.111\right.$, margin $\left.=0.218^{* * *}\right)$ compared to the baseline. Here, the vegetarian spaghetti Bolognese was an exception $\left(\beta=0.217\right.$, margin $\left.=0.275^{* * *}\right)$, being favoured even more than the chickpea curry (base, margin $=$ $\left.0.234^{* * *}\right)$. Rice bowl sales were noticeably lower $\left(\beta=-0.770^{* * *}\right.$, margin $\left.=0.124^{* * *}\right)$. At the university cafeteria, label nudges worked best, increasing most sustainable dish sales by relative $18 \%\left(\beta=0.213^{* *}\right.$, margin $\left.=0.220^{* * *}\right)$ compared to the baseline, while counter position nudges led to a relative increase by $12 \%\left(\beta=0.146^{*}\right.$, margin $=$ $\left.0.209^{* * *}\right)$ and menu position nudges by $7 \%\left(\beta=0.083\right.$, margin $\left.=0.199^{* * *}\right)$. Here, the chickpea curry (base, margin $\left.=0.224^{* * *}\right)$ was favoured, followed by the vegetarian spaghetti Bolognese $\left(\beta=-0.042\right.$, margin $\left.=0.217^{* * *}\right)$ and the potato bowl $\left(\beta=-0.054\right.$, margin $\left.=0.215^{* * *}\right)$. Chicken fricassee sales remained low $\left(\beta=-0.956^{* * *}\right.$, $\left.\operatorname{margin}=0.100^{* * *}\right)$. Overall, the highest sales of most sustainable dishes were recorded at the hospital staff cafeteria. Possible explanations might be location-specific dish preparations, including high shares of organic and fair trade ingredients, which also increased their respective sustainability ratings. 
Appendix Table A6. Results for NAHGAST II - Predictive margins for dish sale shares.

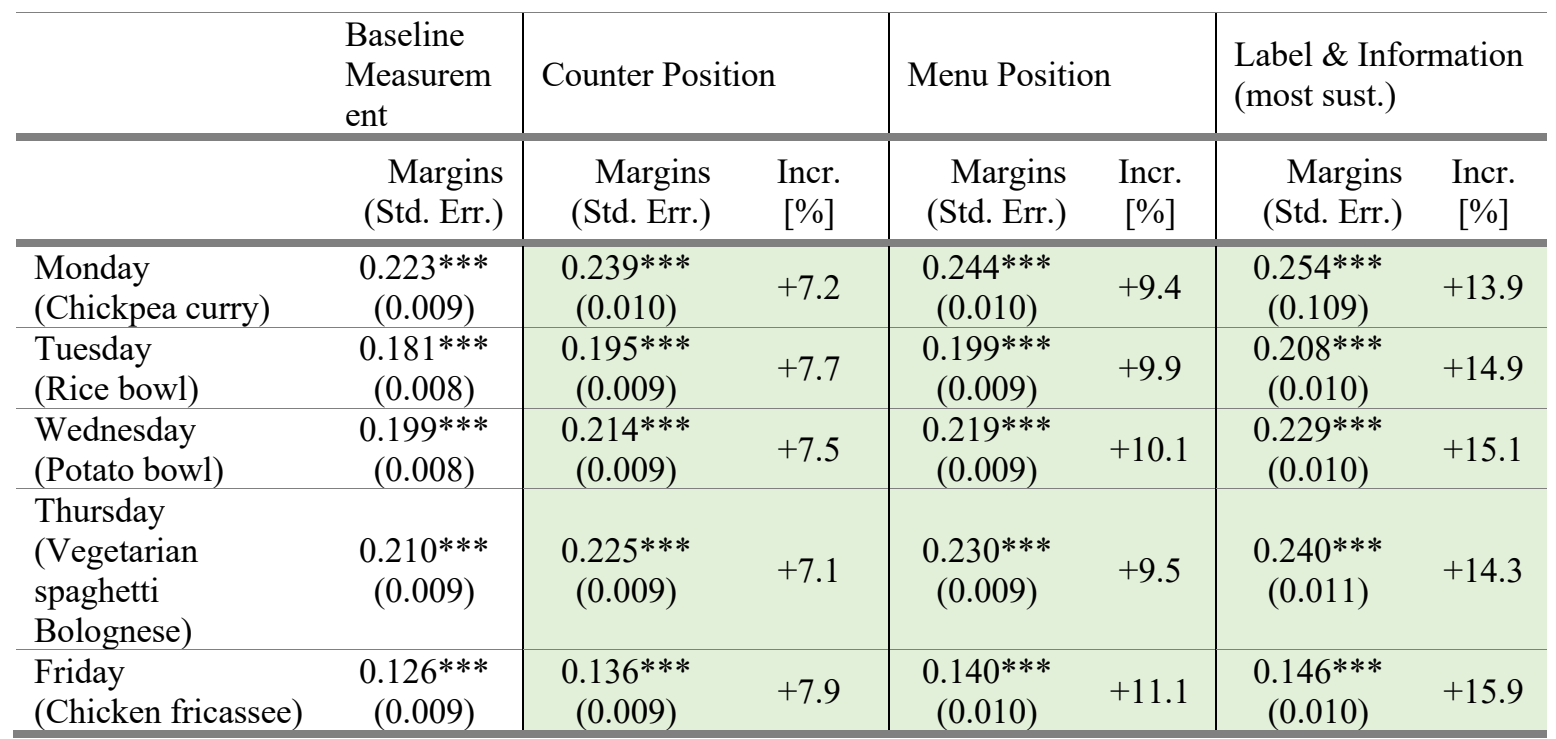

Note: $* * * \mathrm{p}<0.001, * * \mathrm{p}<0.01, * \mathrm{p}<0.05$. 
Appendix Table A7. NAHGAST II results - Logistic Regression and predictive margins for the company and university cafeteria (dependent variable (DV): Choice of most sustainable dish, independent variable (IV): Intervention variant, Day of the week, cafeteria type).

\begin{tabular}{|c|c|c|c|c|}
\hline Choice of most sustainable dish & Coefficient & $\begin{array}{r}\text { Standard } \\
\text { Error }\end{array}$ & Margins & $\begin{array}{r}\text { Standard } \\
\text { Error }\end{array}$ \\
\hline \multicolumn{5}{|l|}{ Intervention } \\
\hline Baseline Measurement & 0 & (base) & $0.189 * * *$ & 0.007 \\
\hline Counter Position & $0.139 *$ & 0.062 & $0.211 * * *$ & 0.007 \\
\hline Menu Position & 0.083 & 0.062 & $0.202 * * *$ & 0.007 \\
\hline $\begin{array}{l}\text { Label \& Information } \\
\text { (most sustainable dish) }\end{array}$ & $0.190 * *$ & 0.068 & $0.219 * * *$ & 0.009 \\
\hline \multicolumn{5}{|l|}{ Day } \\
\hline $\begin{array}{l}\text { Monday } \\
\text { (Chickpea curry) }\end{array}$ & 0 & (base) & $0.226^{* * *}$ & 0.008 \\
\hline $\begin{array}{l}\text { Tuesday } \\
\text { (Rice bowl) }\end{array}$ & $-0.237 * * *$ & 0.067 & $0.188 * * *$ & 0.007 \\
\hline $\begin{array}{l}\text { Wednesday } \\
\text { (Potato bowl) }\end{array}$ & -0.055 & 0.066 & $0.217 * * *$ & 0.008 \\
\hline $\begin{array}{l}\text { Thursday } \\
\text { (Vegetarian spaghetti Bolognese) }\end{array}$ & 0.007 & 0.066 & $0.228 * * *$ & 0.008 \\
\hline $\begin{array}{l}\text { Friday } \\
\text { (Chicken fricassee) }\end{array}$ & $-0.973 * * *$ & 0.112 & $0.100 * * *$ & 0.009 \\
\hline \multicolumn{5}{|l|}{ Cafeteria } \\
\hline Company & 0 & (base) & $0.200 * * *$ & 0.008 \\
\hline University & 0.027 & 0.058 & $0.204^{* * *}$ & 0.004 \\
\hline constant & $-1.345^{* * *}$ & 0.076 & - & - \\
\hline Number of observations & 12,047 & & & \\
\hline Pseudo $\mathrm{R}^{2}$ & 0.0098 & & & \\
\hline Log likelihood & -6025.76 & & & \\
\hline
\end{tabular}

Note: $* * * \mathrm{p}<0.001, * * \mathrm{p}<0.01, * \mathrm{p}<0.05$.

Counter position nudges increased relative sales of most sustainable dishes for the company and university cafeterias in NAHGAST II by $11.6 \%\left(\beta=0.139^{*}\right.$, margin $\left.=0.211^{* * *}\right)$, label nudges by $15.9 \%\left(\beta=0.190^{* *}\right.$, $\left.\operatorname{margin}=0.219^{* * *}\right)$, and menu position nudges by $6.9 \%(\beta=0.083$, margin $=0.202 * * *)$ compared to our NAHGAST II baseline. 
Appendix Figure A1: Model combination of ecological systems theory and food choice process model. Illustrating possible places, time and opportunities to alter and to assess consumer behaviour out-of-home.
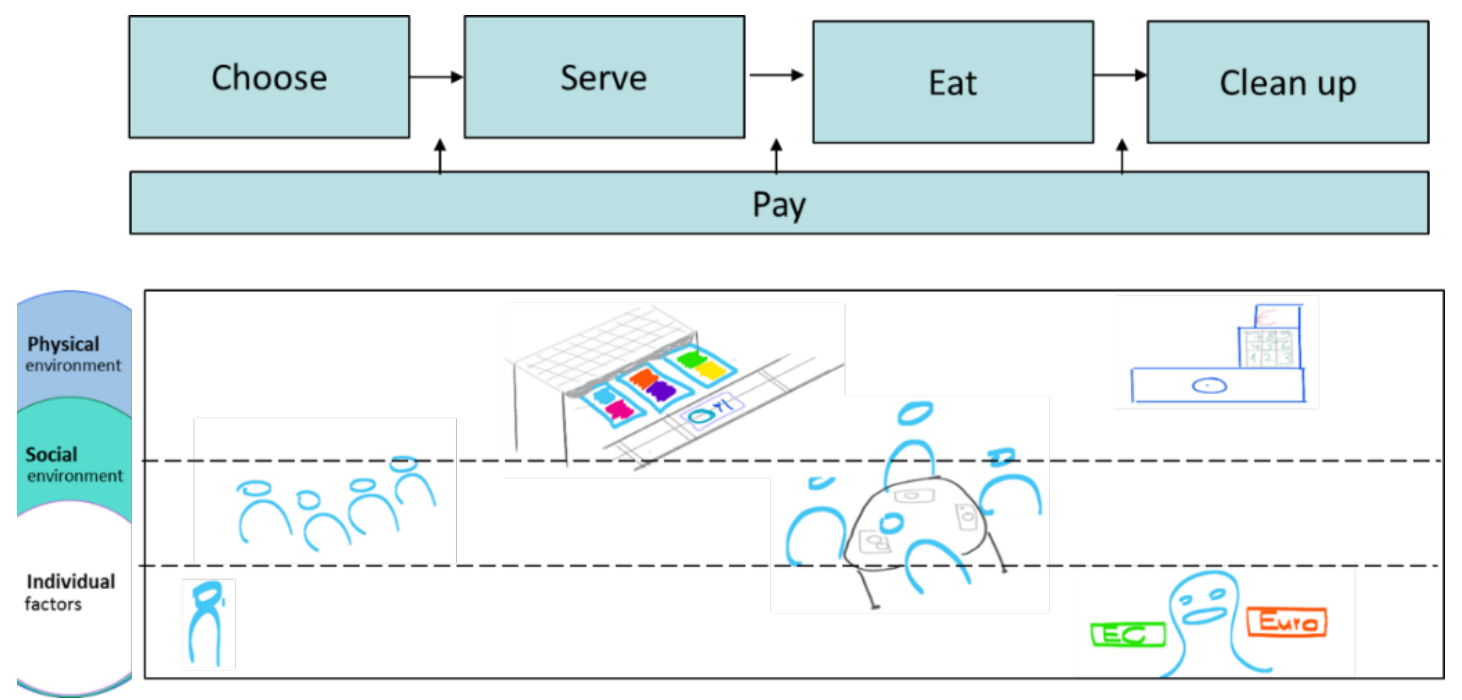

Source: own depiction based on the concepts of Bronfenbrenner (1992) and Sobal \& Bisogni (2009).

Note: Divided into the vertical categories of the ecological systems theory (physical environment, social environment, individual factors) and the horizontal categories of the food choice process model (choose, serve, eat, clean up and pay) in the form of a matrix. Illustrations display few of many possible factors which influence consumer behaviour out-of-home (choice behaviour in a group vs. alone, serving the dish at the counter using a serving tray or not and the e.g. position of the 'green' food in the counter, communication of information at the table, the clearing system as well as the payment system and possible pain of paying depending on payment in cash or not illustrated as ghost). 
Appendix Figure A2. Nudge: Change of the counter position. Exemplary graphical comparison between baseline measurement and intervention week.
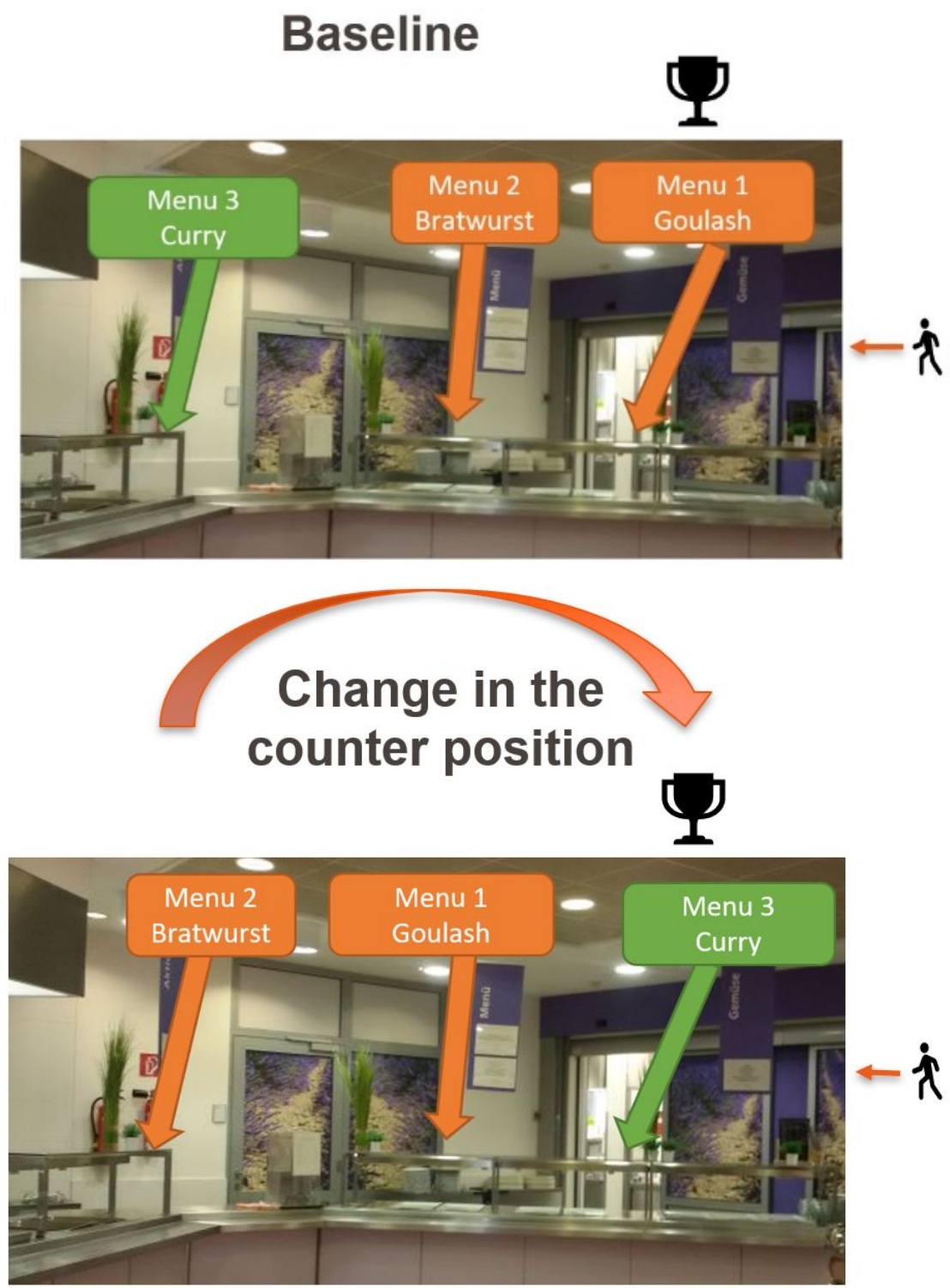

Note: According to kitchen chef experience and sales data, the cafeteria's best-selling position is marked by the trophy far right. Consequently, in the baseline measurement the most sustainable dish of the day according to the evaluation tool, the curry, was not offered in the best-selling position 1 (right) but in position 3 (left). In the intervention week, the most sustainable dish of the day was placed in the best serving position for all contributing cafeterias, in this case on the far right, in order to test the effect of the nudge compared to the baseline. 
Appendix Figure A3. Nudge: Change of the menu position. Exemplary graphical comparison between baseline measurement and intervention week.
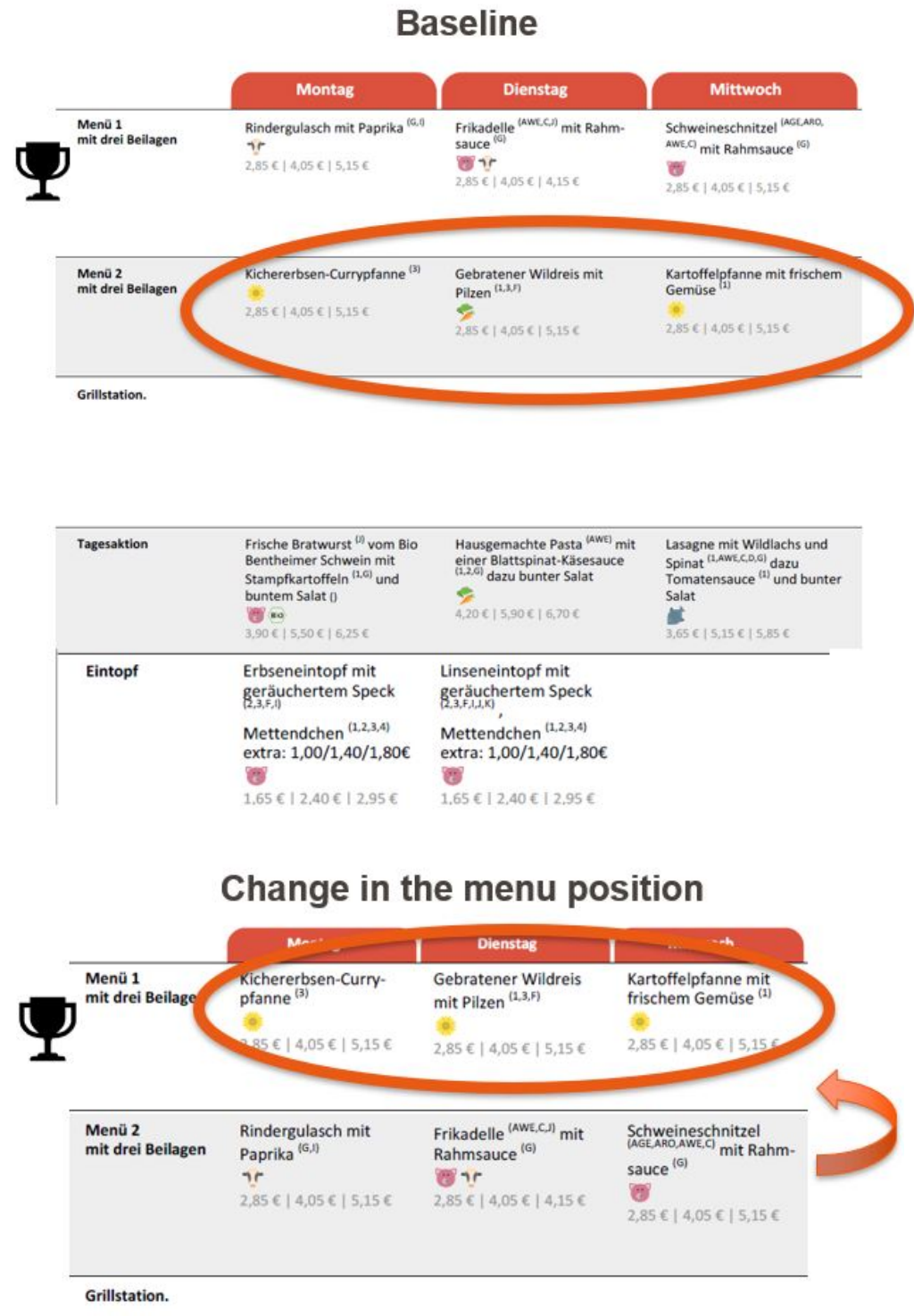

\begin{tabular}{|c|c|c|c|}
\hline Tagesaktion & $\begin{array}{l}\text { Frische Bratwurst }{ }^{(1)} \\
\text { vom Bio Bentheimer } \\
\text { Schwein mit Rahm- } \\
\text { sauce, Stampf- } \\
\text { kartoffeln }{ }^{(1,6)} \text { und } \\
\text { Salat } \\
\text { B, } \\
3,90 \mathrm{C}|5,50 \mathrm{C}| 6,25 \mathrm{C}\end{array}$ & $\begin{array}{l}\text { Hausgemachte Pasta } \\
\text { AWE) mit einer Blatt- } \\
\text { spinat-Käsesauce } \\
\text { dazu bunter Salat } \\
\text { \% } \\
4,20 €|5,90 €| 6,70 €\end{array}$ & $\begin{array}{l}\text { Lasagne mit Wildlachs } \\
\text { und Spinat }{ }^{(1, a w E, C, D, G)} \\
\text { dazu Tomatensauce }{ }^{(1)} \\
\text { und bunter Salat } \\
3,65 \mathrm{C}|5,15 \mathrm{E}| 5,85 \mathrm{C}\end{array}$ \\
\hline Eintopf & 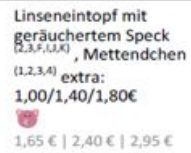 & 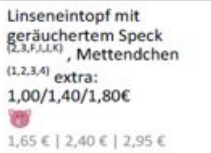 & \\
\hline
\end{tabular}

Note: According to literature and sales data, the cafeteria's best-selling menu position is marked by the trophy at the top (menu 1). Consequently, in the baseline measurement the most sustainable dishes of the day according to the evaluation tool, were not offered in the best-selling menu position at the top (menu 1) but in the middle (menu 2). In the intervention week, the most sustainable dishes of the day were placed in the best menu positions at the top (menu 1) for all contributing cafeterias, in order to test the effect of the nudge compared to the baseline. Exemplary English translation for the baseline; Monday: Beef goulash (menu 1), Chickpea curry (2), Bratwurst 
(3), Pea stew (4); Tuesday: Meatballs (1), Rice bowl (2), Pasta (3), Lentin stew (4); Wednesday: Pork schnitzel (1), Potato bowl (2), Spinach salmon lasagna (3).

Appendix Figure A4. Nudge: Label (left) and explanatory information (right) used in NAHGAST I.

\section{Vegetarischer \\ Gemüseeintopf}

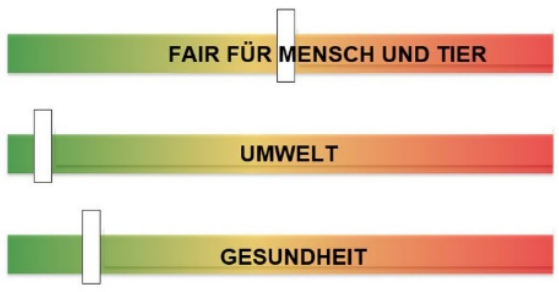

(Speisenbewertung aus Sicht der Nachhaltigkeit durch die NAHGAST-Verbundpartner Wuppertal Institut und Faktor10)

www.nahgast.de

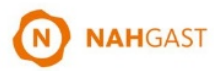

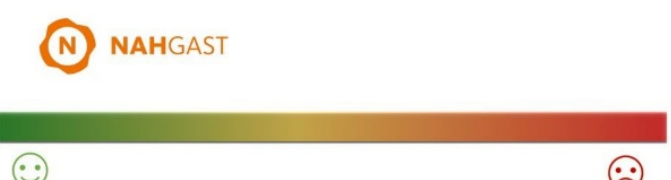

Diese Label bewerten die Nachhaltigkeit der angebotenen Gerichte.

Hinter jeder der drei Kategorien steht eine Vielzahl von Indikatoren. Diese Indikatoren wurden von Wissenschaftlern der TU Berlin gemeinsam mit den Wissenschaftlern des NAHGAST-Projektes zusammengestellt. In intensiver Abstimmung mit den Mitarbeiter*innen von PACE konnte für die hie

Was verbirgt sich hinter:

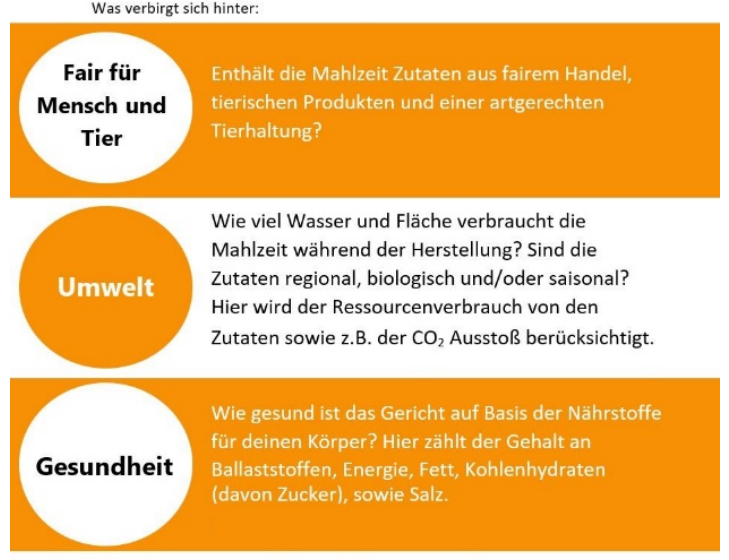

Note: English translation for Label (left): Vegetarian vegetable stew; Scales: Fair for humans and animals, environment, health; Dish evaluation from the sustainability perspective by the NAHGAST alliance partners Wuppertal and Faktor 10. English translation for explanatory information (right): These labels assess the sustainability of the dishes on offer. Behind each of the three categories is a variety of indicators. These indicators were compiled by scientists from the TU Berlin together with the scientists from the NAHGAST project. In intensive coordination with the employees, it was possible to carry out the sustainability evaluation for the dishes offered here. What is behind: Fair for humans and animals: Does the meal contain ingredients from fair trade, animal products and species-appropriate animal husbandry? Environment: How much water and land does the meal use during production? Are the ingredients regional, organic and/or seasonal? Here, resource consumption from ingredients is considered, as well as $\mathrm{CO} 2$ emissions. Health: How healthy is the meal for your body based on the nutrients? Here the content of fiber, energy, fat, carbohydrates (of which sugar), as well as salt counts. 
Appendix Figure A5. Nudge: Label and explanatory information used in NAHGAST II.

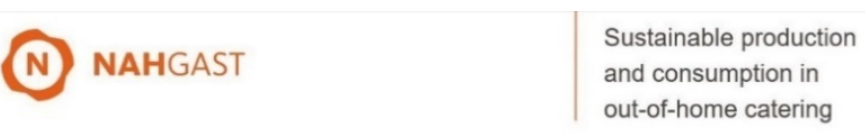

\section{Exemplary Dish}

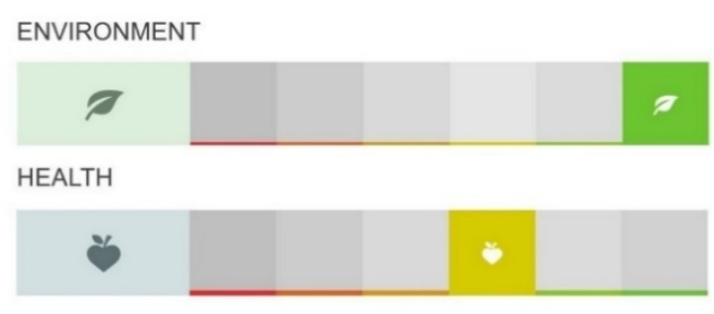

FAIRNESS FOR HUMANS AND ANIMALS

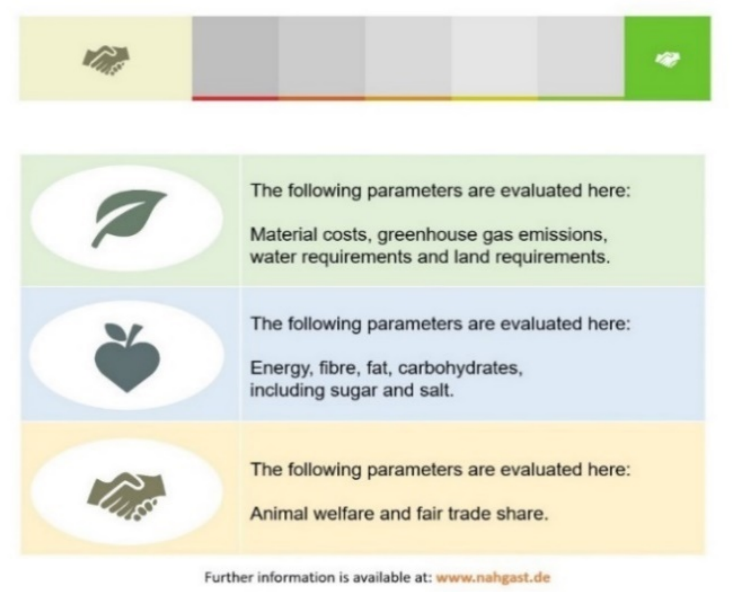

Note: Translated English version. German version can be provided upon request. 


\section{References}

Arno, A., Thomas, S., 2016. The efficacy of nudge theory strategies in influencing adult dietary behaviour: a systematic review and meta-analysis. BMC public health 16, 676. https://doi.org/10.1186/s12889-016-3272-x

Bauer, J.M., Bietz, S., Rauber, J., Reisch, L.A., 2021. Nudging healthier food choices in a cafeteria setting: A sequential multi-intervention field study. Appetite 160, 105106.

Bell, R., Marshall, D.W., 2003. The construct of food involvement in behavioral research: scale development and validation $\boldsymbol{i}^{2}$. Appetite 40, 235-244.

Black, R.E., 2013. What makes good nutrition so important? The Lancet 382, 427-451.

Broers, V.J., De Breucker, C., Van den Broucke, S., Luminet, O., 2017. A systematic review and meta-analysis of the effectiveness of nudging to increase fruit and vegetable choice. The European Journal of Public Health 27, $912-$ 920.

Bronfenbrenner, U., 1992. Ecological systems theory. Jessica Kingsley Publishers, London.

Bucher, T., Collins, C., Rollo, M.E., McCaffrey, T.A., De Vlieger, N., Van der Bend, D., Truby, H., Perez-Cueto, F.J., 2016. Nudging consumers towards healthier choices: a systematic review of positional influences on food choice. British Journal of Nutrition 115, 2252-2263. https://doi.org/10.1017/S0007114516001653

Burlingame, B., Dernini, S., 2012. Sustainable diets and biodiversity directions and solutions for policy, research and action. FAO Headquarters, Rome.

BVE, 2020. Bundesvereinigung der Deutschen Ernährungsindustrie e.V. Jahresbericht 2019_2020 [WWW Document]. URL https://www.bve-online.de/presse/infothek/publikationen-jahresbericht/bve-jahresberichternaehrungsindustrie-2020 (accessed 7.31.20).

BVE, 2019. Bundesvereinigung der Deutschen Ernährungsindustrie e.V. Jahresbericht 2018_2019 [WWW Document]. URL https://www.bve-online.de/presse/infothek/publikationen-jahresbericht/bve-jahresberichternaehrungsindustrie-2019 (accessed 5.7.20).

Campbell-Arvai, V., Arvai, J., Kalof, L., 2014. Motivating sustainable food choices: The role of nudges, value orientation, and information provision. Environment and Behavior 46, 453-475.

Crippa, M., Solazzo, E., Guizzardi, D., Monforti-Ferrario, F., Tubiello, F.N., Leip, A., 2021. Food systems are responsible for a third of global anthropogenic GHG emissions. Nature Food 1-12.

Dayan, E., Bar-Hillel, M., 2011. Nudge to nobesity II: Menu positions influence food orders. Judgment and Decision Making 6, 333-342.

Dhar, R., Novemsky, N., 2008. Beyond rationality: The content of preferences. Journal of Consumer Psychology 18, 175178.

Engelmann, T., Speck, M., Rohn, H., Bienge, K., Langen, N., Howell, E., Göbel, C., Friedrich, S., Teitscheid, P., Bowry, J., 2018. Sustainability assessment of out-of-home meals: potentials and challenges of applying the indicator sets NAHGAST meal-basic and NAHGAST meal-pro. Sustainability 10, 562.

Filimonau, V., Lemmer, C., Marshall, D., Bejjani, G., 2017. 'Nudging' as an architect of more responsible consumer choice in food service provision: The role of restaurant menu design. Journal of Cleaner Production 144, 161170. https://doi.org/10.1016/j.jclepro.2017.01.010

FridaysForFuture, 2019. Global Climate Strike For Future [WWW Document]. URL https://www.fridaysforfuture.org/

Göbel, C., Langen, N., Blumenthal, A., Teitscheid, P., Ritter, G., 2015. Cutting food waste through cooperation along the food supply chain. Sustainability 7, 1429-1445.

Göbel, C., Scheiper, M.-L., Friedrich, S., Teitscheid, P., Rohn, H., Speck, M., Langen, N., 2017. Entwicklung eines Leitbilds zur „Nachhaltigkeit in der Auls ser-Haus-Gastronomie “, in: Innovation in Der Nachhaltigkeitsforschung. Springer, pp. 1-21. 
Groß, M., Hoffmann-Riem, H., Krohn, W., 2005. Realexperimente: ökologische Gestaltungsprozesse in der Wissensgesellschaft. transcript Verlag.

Grunert, K.G., Wills, J.M., 2007. A review of European research on consumer response to nutrition information on food labels. Journal of public health 15, 385-399.

Hanks, A.S., Just, D.R., Smith, L.E., Wansink, B., 2012. Healthy convenience: nudging students toward healthier choices in the lunchroom. Journal of Public Health 34, 370-376.

Harbers, M.C., Beulens, J.W., Rutters, F., de Boer, F., Gillebaart, M., Sluijs, I., van der Schouw, Y.T., 2020. The effects of nudges on purchases, food choice, and energy intake or content of purchases in real-life food purchasing environments: a systematic review and evidence synthesis. Nutrition journal 19, 1-27.

Ivanova, D., Barrett, J., Wiedenhofer, D., Macura, B., Callaghan, M., Creutzig, F., 2020. Quantifying the potential for climate change mitigation of consumption options. Environmental Research Letters 15, 093001.

Janßen, D., Langen, N., 2017. The bunch of sustainability labels - Do consumers differentiate? Journal of Cleaner Production 143, 1233-1245. https://doi.org/10.1016/j.jclepro.2016.11.171

Jung, J.Y., Mellers, B.A., 2016. American attitudes toward nudges. Judgment \& Decision Making 11.

Just, D.R., Wansink, B., 2009. Smarter lunchrooms: using behavioral economics to improve meal selection. Choices 24, $1-7$.

Kahneman, D., 2011. Thinking, fast and slow. Macmillan, New York, NY, USA.

Kasim, A., Ismail, A., 2012. Environmentally friendly practices among restaurants: drivers and barriers to change. Journal of Sustainable Tourism 20, 551-570.

Langen, N., 2018. Interventionen und Stellschrauben für nachhaltige Ernährung in der AHG, in: Teitscheid, P., Langen, N., Speck, M., Rohn, H. (Eds.), Nachhaltig Außer-Haus Essen. Oekom, München, pp. 266-291.

Langen, N., Rhozyel, M., Göbel, C., Speck, M., Engelmann, T., Rohn, H., Teitscheid, P., 2017. Displaying Sustainability Related Information on Meals - The Role of Design and Information Depth from a Consumer's Perspective. Proceedings in Food System Dynamics 349-459 Pages. https://doi.org/10.18461/PFSD.2017.1737

Lehner, M., Mont, O., Heiskanen, E., 2016. Nudging-A promising tool for sustainable consumption behaviour? Journal of Cleaner Production 134, 166-177.

Levy, D.E., Riis, J., Sonnenberg, L.M., Barraclough, S.J., Thorndike, A.N., 2012. Food choices of minority and lowincome employees: a cafeteria intervention. American journal of preventive medicine 43, 240-248.

Lin, Y., Osman, M, Ashcroft, R. 2017. Nudge: Concept, Effectiveness, and Ethics. Basic and Applied Social Psychology 39, 6, 293-306.

Lorenz, B.A., Hartmann, M., Hirsch, S., Kanz, O., Langen, N., 2017. Determinants of plate leftovers in one German catering company. Sustainability $9,807$.

Lorenz-Walther, B.A.-S., Langen, N., 2020. Sustainable changes in a worksite canteen: An exploratory study on the acceptance of guests. Journal of Cleaner Production 259, 120737.

Mbow, C., Rosenzweig, C., Barioni, L.G., Benton, T.G., Herrero, M., Krishnapillai, M., Liwenga, E., Pradhan, P., RiveraFerre, M.G., Sapkota, T., 2019. Food security. In: Climate Change and Land: an IPCC special report on climate change, desertification, land degradation, sustainable land management, food security, and greenhouse gas fluxes in terrestrial ecosystems.

Melissen, F., 2013. Sustainable hospitality: a meaningful notion? Journal of sustainable tourism 21, 810-824.

Miller, L.M.S., Cassady, D.L., 2015. The effects of nutrition knowledge on food label use. A review of the literature. Appetite 92, 207-216.

Monetti, S., Pregernig, M., Speck, M., Langen, N., Bienge, K., 2021. Assessing the impact of individual nutrition on biodiversity: A conceptual framework for the selection of indicators targeted at the out-of-home catering sector. Ecological Indicators 126, 107620. https://doi.org/10.1016/j.ecolind.2021.107620 
Morizet, D., Depezay, L., Combris, P., Picard, D., Giboreau, A., 2012. Effect of labeling on new vegetable dish acceptance in preadolescent children. Appetite 59, 399-402.

Myung, E., McClaren, A., Li, L., 2012. Environmentally related research in scholarly hospitality journals: Current status and future opportunities. International Journal of Hospitality Management 31, 1264-1275. https://doi.org/10.1016/j.ijhm.2012.03.006

NAHGAST, 2020. NAHGAST - Initiierung, Unterstützung und Verbreitung von Transformationsprozessen zum nachhaltigen Wirtschaften in der Außer-Haus-Gastronomie. [WWW Document]. NAHGAST. URL https://www.nahgast.de/ (accessed 5.7.20).

O’brien, R.M., 2007. A caution regarding rules of thumb for variance inflation factors. Quality \& quantity 41, 673-690.

Ohlhausen, P., Langen, N., 2021. Spontaneous Variety-Seeking Meal Choice in Business Canteens Impedes Sustainable Production. Sustainability $13,746$.

Ohlhausen, P., Langen, N., 2020. When a Combination of Nudges Decreases Sustainable Food Choices Out-Of-HomeThe Example of Food Decoys and Descriptive Name Labels. Foods 9, 557. https://doi.org/10.3390/foods9050557

Ohlhausen, P., Langen, N., Friedrich, S., Speck, M., Bienge, K., Engelmann, T., Rohn, H., Teitscheid, P., 2018. Auf der Suche nach dem wirksamsten Nudge zur Absatzsteigerung nachhaltiger Speisen in der Außer-HausGastronomie. Vierteljahrshefte zur Wirtschaftsforschung 87, 95-108. https://doi.org/10.3790/vjh.87.2.95

Peinelt, V., Wetterau, J., 2015. Handbuch der Gemeinschaftsgastronomie. Rhombos-Verlag.

Poore, J., Nemecek, T., 2018. Reducing food's environmental impacts through producers and consumers. Science 360, 987-992. https://doi.org/10.1126/science.aaq0216

Reisch, L., Eberle, U., Lorek, S., 2013. Sustainable food consumption: an overview of contemporary issues and policies. Sustainability: Science, Practice and Policy 9, 7-25.

Richardson, R., Prescott, M.P., Ellison, B., 2020. Impact of plate shape and size on individual food waste in a university dining hall. Resources, Conservation and Recycling 105293.

Risku-Norja, H., Kurppa, S., Helenius, J., 2009. Dietary choices and greenhouse gas emissions-assessment of impact of vegetarian and organic options at national scale. Progress in Industrial Ecology, an International Journal 6, 340354. https://doi.org/10.1504/PIE.2009.032323

Rockström, J., Sukhdev, P., 2016. How food connects all the SDGs [WWW Document]. Stockholm resilience centre. URL https://www.stockholmresilience.org/research/research-news/2016-06-14-how-food-connects-all-thesdgs.html (accessed 5.26.20).

Rozin, P., Scott, S.E., Dingley, M., Urbanek, J.K., Jiang, H., Kaltenbach, M., 2011. Nudge to nobesity I: Minor changes in accessibility decrease food intake. Judgment and Decision Making 6 (4), 323-332.

Rückert-John, J., 2005. Zukunftsfähigkeit der Ernährung außer Haus. Brunner, Karl-Michael; Schönberger, Gesa U.(Hg.): Nachhaltigkeit und Ernährung. Produktion-Handel-Konsum. Frankfurt am Main: Campus-Verlag 240-262.

Russo, J.E., Staelin, R., Nolan, C.A., Russell, G.J., Metcalf, B.L., 1986. Nutrition information in the supermarket. Journal of Consumer Research 13, 48-70.

Saulais, L., 2015. Responsibility, strategies and perspectives. The Routledge Handbook of Sustainable Food and Gastronomy 253.

Skov, L.R., Lourenco, S., Hansen, G.L., Mikkelsen, B.E., Schofield, C., 2013. Choice architecture as a means to change eating behaviour in self-service settings: a systematic review. Obesity Reviews 14, 187-196. https://doi.org/10.1111/j.1467-789X.2012.01054.X

Sobal, J., Bisogni, C.A., 2009. Constructing food choice decisions. Annals of Behavioral Medicine 38, s37-s46. 
Speck, M., Bienge, K., Wagner, L., Engelmann, T., Schuster, S., Teitscheid, P., Langen, N., 2020. Creating sustainable meals supported by the NAHGAST online tool—approach and effects on GHG emissions and use of natural resources. Sustainability $12,1136$.

StataCorp LP, 2013. Stata user's guide. StataCorp LP, College Station, Tex.

Story, M., Kaphingst, K.M., Robinson-O 'brien, R., Glanz, K., 2008. Creating Healthy Food and Eating Environments: Policy and Environmental Approaches. Annu. Rev. Public Health 29, 253-272. https://doi.org/10.1146/annurev.publhealth.29.020907.090926

Sunstein, C.R., 2016a. The ethics of choice architecture, in: Choice Architecture in Democracies. Nomos Verlagsgesellschaft mbH \& Co. KG, Munich, Germany, pp. 19-74.

Sunstein, C.R., 2016b. People prefer system 2 nudges (kind of). Duke LJ 66, 121.

Teitscheid, P., 2011. Erstes Nachhaltigkeitssiegel für die Betriebsgastronomie [WWW Document]. URL https://www.fhmuenster.de/isun/downloads/110718_Presse_compass.pdf(accessed 11.4.20).

Thaler, R.H., 2015. The power of nudges, for good and bad. The New York Times 31, 2015.

Thaler, R.H., Sunstein, C.R., 2008. Nudge: Improving decisions about health, wealth, and happiness. Penguin, Londun, UK.

Vandenbroele, J., Vermeir, I., Geuens, M., Slabbinck, H., Van Kerckhove, A., 2020. Nudging to get our food choices on a sustainable track. Proceedings of the Nutrition Society 79, 133-146.

Velema, E., Vyth, E.L., Hoekstra, T., Steenhuis, I.H., 2018. Nudging and social marketing techniques encourage employees to make healthier food choices: a randomized controlled trial in 30 worksite cafeterias in The Netherlands. The American journal of clinical nutrition 107, 236-246.

Visschers, V.H., Gundlach, D., Beretta, C., 2020. Smaller servings vs. information provision: Results of two interventions to reduce plate waste in two university canteens. Waste Management 103, 323-333.

Wahlen, S., Heiskanen, E., Aalto, K., 2012. Endorsing sustainable food consumption: Prospects from public catering. Journal of Consumer Policy 35, 7-21. https://doi.org/10.1007/s10603-011-9183-4

Wang, Y.-F., Chen, S.-P., Lee, Y.-C., Tsai, C.-T.S., 2013. Developing green management standards for restaurants: An application of green supply chain management. International Journal of Hospitality Management 34, $263-273$.

Wilson, A.L., Buckley, E., Buckley, J.D., Bogomolova, S., 2016. Nudging healthier food and beverage choices through salience and priming. Evidence from a systematic review. Food Quality and Preference 51, 47-64. https://doi.org/10.1016/j.foodqual.2016.02.009

Winkler, G., Berger, B., Filipiak-Pittroff, B., 2018. Small changes in choice architecture in self-service cafeterias. Do they nudge consumers towards healthier food choices? Ernährungs Umschau 170-178.

https://doi.org/10.4455/eu.2018.038 